\title{
PUBLICATIONS OF RYOJI NOYORI
}

(1) The Stereochemistry of 9,10-Dihydro-9,10-o-xylyleneanthracene Derivatives. K. Sisido, R. Noyori, and H. Nozaki, J. Am. Chem. Soc., 84, 3562 (1962).

(2) Polycondensation of Xylylene Dibromides by Transition Metals in Water Suspension. K. Sisido, N. Kusano, R. Noyori, Y. Nozaki, M. Simosaka, and H. Nozaki, J. Polym. Sci. Part A, l, 2101 (1963).

(3) 9,10-Bridged 9,10-Dihydroanthracenes. K. Sisido, R. Noyori, N. Kôzaki, and H. Nozaki, Tetrahedron, 19, 1185 (1963).

(4) Acetolysis of trans-1,2-Dibromobenzocyclobutene. H. Nozaki, R. Noyori, and N. Kôzaki, Tetrahedron, 20, 641 (1964).

(5) Reaction of Phenylcarbene Formed from Benzaldehyde Tosylhydrazone in Certain Solvents. H. Nozaki, R. Noyori, and K. Sisido, Tetrahedron, 20, 1125 (1964).

(6) Photo-Isomerization of 2,2,5,5-Tetramethyl-1,3-cyclohexanedione. H. Nozaki, Z. Yamaguti, and R. Noyori, Tetrahedron Lett., 37 (1965).

(7) The Reactions of Phenylcarbene with Polynuclear Aromatic Compounds. H. Nozaki, M. Yamabe, and R. Noyori, Tetrahedron, 21, 1657 (1965).

(8) The Photo-Sensitized Isomerization of cis,trans,trans-1,5,9-Cyclododecatriene. $\quad H$. Nozaki, Y. Nisikawa, Y. Kamatani, and R. Noyori, Tetrahedron Lett., 2161 (1965).

(9) The Reaction of Ethyl Diazoacetate with Styrene Oxide. H. Nozaki, H. Takaya, and R. Noyori, Tetrahedron Lett., 2563 (1965).

(10) Preparation of cis-Cyclododecene, Cyclododecyne, and Cyclododecanone. H. Nozaki and R. Noyori, J. Org. Chem., 30, 1652 (1965).

(11) The Simmons-Smith Reaction of trans, trans, cis-1,5,9-Cyclododecatriene. H. Nozaki, M. Kawanisi, and R. Noyori, J. Org. Chem., 30, 2216 (1965).

(12) Reactions of Diphenyldiazomethane in the Presence of Bis(acetylacetonato)copper(II). Modified Diphenylmethylene Reactions. H. Nozaki, S. Moriuti, M. Yamabe, and R. Noyori, Tetrahedron Lett., 59 (1966).

(13) Nucleophilic Aromatic Methylation with Methylsulphinylcarbanion. H. Nozaki, Y. Yamamoto, and R. Noyori, Tetrahedron Lett., 1123 (1966).

(14) The Stereoselective Addition of Dihalocarbenes to cis,trans,trans-Cyclododeca-1,5,9triene and the Synthesis of Cyclotridecanone. H. Nozaki, S. Katô, and R. Noyori, Can. J. Chem., 44, 1021 (1966).

(15) Preparation and Photochemical Isomerization of 2-Cyclododecenones. H. Nozaki, T. Mori, and R. Noyori, Tetrahedron, 22, 1207 (1966).

(16) Chemistry of Xylylenes and Related Compounds. H. Nozaki, R. Noyori, and K. Sisido, Nippon Kagaku Zasshi, 87, 641 (1966).

(17) Debromination with Iron Powder in Water Suspension. Synthesis of Cyclic Hydrocarbons. H. Nozaki and R. Noyori, Tetrahedron, 22, 2163 (1966).

(18) Photochemical Rearrangement of Arenesulphonanilides to $p$-Aminodiarylsulphones. H. Nozaki, T. Okada, R. Noyori, and M. Kawanisi, Tetrahedron, 22, 2177 (1966).

(19) Asymmetric Induction in Carbenoid Reaction by Means of a Dissymmetric Copper Chelate. H. Nozaki, S. Moriuti, H. Takaya, and R. Noyori, Tetrahedron Lett., 5239 (1966).

(20) Reaction of Carbethoxycarbene with 2-Phenyloxirane and 2-Phenyloxetane. H. Nozaki, H. Takaya, and R. Noyori, Tetrahedron, 22, 3393 (1966).

(21) Diimide Reduction of 12-Membered Cyclic Olefins. H. Nozaki, Y. Simokawa, T. Mori and R. Noyori, Can. J. Chem., 44, 2921 (1966).

(22) Photochemical Reaction of Ethyl Azidoformate with Cyclic Ethers and Acetals. H. Nozaki, S. Fujita, H. Takaya, and R. Noyori, Tetrahedron, 23, 45 (1967). 
(23) Aspects of Reactions of Carbenes and Their Complexes. H. Nozaki, H. Takaya, and R. Noyori, Nippon Kagaku Zasshi, 87, 1261 (1966).

(24) A Novel Synthesis of Cyclopentadecanone from Cyclododecanone. H. Nozaki, T. Mori, and R. Noyori, Tetrahedron Lett., 779 (1967).

(25) The cis-trans Isomerization of Twelve-Membered Cyclic Olefins. H. Nozaki, Y. Nisikawa, M. Kawanisi, and R. Noyori, Tetrahedron, 23, 2173 (1967).

(26) The Synthesis from Cyclododecanone of Novel Substances Having a Musk-like Odor. H. Nozaki, T Mori, R. Noyori, and M. Kawanisi, Can. J. Chem., 45, 1804 (1967).

(27) Reduction of gem-Dibromocyclopropanes with Chromium(II) Sulphate. H. Nozaki, T Aratani, and R. Noyori, Tetrahedron, 23, 3645 (1967).

(28) Photochemistry of Certain Non-enolizable $\beta$-Diketones. H. Nozaki, Z. Yamaguti, T. Okada, R. Noyori, and M. Kawanisi, Tetrahedron, 23, 3993 (1967).

(29) Photochemical Alkylation of Nitrogen Heteroaromatics by Carboxylic Acids under Decarboxylation. H. Nozaki, M. Katô, R. Noyori, and M. Kawanisi, Tetrahedron Lett., 4259 (1967).

(30) Photochemical Behaviour of Enolic $\beta$-Diketones Towards Cycloolefins. H. Nozaki, M. Kurita, T. Mori, and R. Noyori, Tetrahedron, 24, 1821 (1968).

(31) Photochemical Reactions of trans-Anethole. H. Nozaki, I. Otani, R. Noyori, and M. Kawanisi, Tetrahedron, 24, 2183 (1968).

(32) The Photochemistry of 1,2,3-Triphenylaziridine. H. Nozaki, S. Fujita, and R. Noyori, Tetrahedron, 24, 2193 (1968).

(33) Photo-Induced Polar Addition of Protic Solvents to 2-Cycloheptenone. H. Nozaki, M. Kurita, and R. Noyori, Tetrahedron Lett., 2025 (1968).

(34) Asymmetric Ring Opening of gem-Dibromocyclopropanes Leading to Allenic Hydrocarbons. H. Nozaki, T. Aratani, and R. Noyori, Tetrahedron Lett., 2087 (1968).

(35) Synthesis of Certain [8](2,5)Heterophanes. H. Nozaki, T. Koyama, T. Mori, and R. Noyori, Tetrahedron Lett., 2181 (1968).

(36) Synthetic Studies on Cyclic Compounds by Means of Photochemically Excited Species. H. Nozaki, T. Okada, T. Mori, R. Noyori, and M. Kawanisi, Nippon Kagaku Zasshi, 89, 215 (1968).

(37) Homogeneous Catalysis in the Decomposition of Diazo Compounds by Copper Chelates. Asymmetric Carbenoid Reactions. H. Nozaki, H. Takaya, S. Moriuti, and R. Noyori, Tetrahedron, 24, 3655 (1968).

(38) Photochemical Reactions of 2,6-Cycloheptadienone. H. Nozaki, M. Kurita, and R. Noyori, Tetrahedron Lett., 3635 (1968).

(39) Photochemical Reaction of 2,7-Cyclooctadienone in Protic Solvents. R. Noyori and M. Katô, Tetrahedron Lett., 5075 (1968).

(40) The Reactive Intermediate in the Photoinduced Alcohol Addition of cis-2-Cyclooctenone. R. Noyori, A. Watanabe, and M. Katô, Tetrahedron Lett., 5443 (1968).

(41) Photolysis of Bis(benzenesulfonyl)diazomethane and Vinyl Polymerization Induced by the Photolysates. H. Nozaki, T. Sakai, H. Takaya, and R. Noyori, Kogyo Kagaku Zasshi, 72, 280 (1969).

(42) Reaction of Methylenecyclopropanes with Enneacarbonyldi-iron: A New Route Tricarbonyltrimethylenemethaneiron Complexes. R. Noyori, T. Nishimura, and H. Takaya, Chem. Commun., 89 (1969).

(43) Partial Asymmetric Synthesis of Methylenecyclopropanes and Spiropentanes. R. Noyori, H. Takaya, Y. Nakanisi, and H. Nozaki, Can. J. Chem., 47, 1242 (1969).

(44) Photochemical Reaction of Benzopyridines with Alkanoic Acids. Novel Reductive Alkylation of Acridine, Quinoline, and Isoquinoline under Decarboxylation. R. Noyori, M. Katô, M. Kawanisi, and H. Nozaki, Tetrahedron, 25, 1125 (1969). 
(45) Retro-Diels-Alder Reaction Induced by $\pi, \pi^{*}$ Excitation and by Electron Impact. $H$. Nozaki, H. Katô, and R. Noyori, Tetrahedron, 25, 1661 (1969).

(46) Reaction of Methylenecyclopropanes with Palladium Chloride. R. Noyori and H. Takaya, Chem. Commun., 525 (1969).

(47) A Total Synthesis of Prostaglandin $\mathrm{F}_{2 \alpha}(d l)$ from 2-Oxabicyclo[3.3.0]oct-6-en-3-one. E. J. Corey and R. Noyori, Tetrahedron Lett., 311 (1970).

(48) Total Synthesis of Prostaglandins $F_{1 \alpha}, E_{1}, F_{2} \alpha$, and $E_{2}$ (Natural Forms) from a Common Synthetic Intermediate. $\quad$ E. J. Corey, R. Noyori, and T. K. Schaaf, J. Am. Chem. Soc., 92, $2586(1970)$.

(49) Nickel(0)-Catalyzed Reaction of Methylenecyclopropanes with Olefins. A Novel $\left[\sigma^{2}\right.$ $+{ }_{\pi}^{2}$ ] Cycloaddition. $\quad$ R. Noyori, T. Odagi, and H. Takaya, J. Am. Chem. Soc., 92, 5780 (1970).

(50) Reaction of Methylenecyclopropanes with Lead Tetra-acetate. R. Noyori, Y. Tsuda, and H. Takaya, Chem. Commun., 1181 (1970).

(51) Photolysis of 1-Acetylcyclooctene. Direct Observation of Dienol Intermediate in Photochemical Deconjugation of $\alpha, \beta$-Unsaturated Ketone. $\quad$ R. Noyori, H. Inoue, and M. Katô, J. Am. Chem. Soc., 92, 6699 (1970).

(52) Divergence of the Photochemical Reaction of Cyclo-octa-2,6-dienone. R. Noyori, H. Inoue, and M. Katô, Chem. Commun., 1695 (1970).

(53) Reaction of $\alpha, \alpha^{\prime}$-Dibromo Ketones with Iron Carbonyls in the Presence of 1,3-Dienes. A New Route to Troponoid Compounds. R. Noyori, S. Makino, and H. Takaya, J. Am. Chem. Soc., 93, 1272 (1971).

(54) Asymmetric Syntheses by Means of (-)-Sparteine Modified Organometallic Reagents. H. Nozaki, T. Aratani, T. Toraya, and R. Noyori, Tetrahedron, 27, 905 (1971).

(55) Photo-Induced Cyclization of cis,cis-2,8-Cyclononadienone via the cis,trans Isomer. R. Noyori, Y. Ohnishi, and M. Katô, Tetrahedron Lett., 1515 (1971).

(56) A New Synthesis of $\alpha, \beta$-Unsaturated Aldehydes Using 1,3-Bis(methylthio)allyllithium. E. J. Corey, B. W. Erickson, and R. Noyori, J. Am. Chem. Soc., 93, 1724 (1971).

(58) Nickel(0)-Catalyzed Reaction of Bicyclo[1.1.0]butanes with Olefins. R. Noyori, T. Suzuki, Y. Kumagai, and H. Takaya, J. Am. Chem. Soc., 93, 5894 (1971).

(59) Nickel(0)-Catalyzed Reaction of Bicyclo[2.1.0]pentane with Olefins. R. Noyori, T. Suzuki, and H. Takaya, J. Am. Chem. Soc., 93, 5896 (1971).

(60) Reaction of $\alpha, \alpha^{\prime}$-Dibromo Ketones and Enamines with the Aid of Iron Carbonyls. A Novel Cyclopentenone Synthesis. R. Noyori, K. Yokoyama, S. Makino, and Y. Hayakawa, J. Am. Chem. Soc., 94, 1772 (1972).

(61) Selective Hydrogenation of $\alpha, \beta$-Unsaturated Carbonyl Compounds via Hydridoiron Complexes. $\quad$ R. Noyori, I. Umeda, and T. Ishigami, J. Org. Chem., 37, 1542 (1972).

(62) Nickel(0)-Catalyzed Reaction of Methylenecyclopropane with Olefins. Orientation and Stereochemistry. $\quad$ R. Noyori, Y. Kumagai, I. Umeda, and H. Takaya, J. Am. Chem. Soc., 94, 4018 (1972).

(63) Photochemistry of 2,6-Cycloheptadienones in Strong Acid. A Protonated Version of Cycloheptadienone-Oxyheptatrienyl Transformation. R. Noyori, Y. Ohnishi, and M. Katô, J. Am. Chem. Soc., 94, 5105 (1972).

(64) Mechanistic Aspects of the Reaction of $\alpha, \alpha^{\prime}$-Dibromo Ketones and Iron Carbonyl. Reductive Rearrangements of Dibromo Ketones. R. Noyori, Y. Hayakawa, M. Funakura, H. Takaya, S. Murai, R. Kobayashi, and S. Tsutsumi, J. Am. Chem. Soc., 94, 7202 (1972). 
(65) Nickel(0)-Catalyzed Dimerization of Cyclopropenones. R. Noyori, I. Umeda, and H. Takaya, Chem. Lett., 1189 (1972).

(66) A Convenient Route to 4,5-Homotropones. R. Noyori, Y. Hayakawa, S. Makino, and H. Takaya, Chem. Lett., 3 (1973).

(67) Transition Metal Catalyzed [2 + 2] Cross-Addition of Olefins. Nickel(0)-Catalyzed Cycloaddition of Norbornadiene and Methylenecyclopropane. R. Noyori, T. Ishigami, N. Hayashi, and H. Takaya, J. Am. Chem. Soc., 95, 1674 (1973).

(68) On the Nature of Carbenoids Generated from Bicyclo[1.1.0]butanes and Transition Metal Complexes. R. Noyori, Tetrahedron Lett., 1691 (1973).

(69) Reaction of $\alpha, \alpha^{\prime}$-Dibromo Ketones with Iron Carbonyls in the Presence of FiveMembered Heterocycles. R. Noyori, Y. Baba, S. Makino, and H. Takaya, Tetrahedron Lett., 1741 (1973).

(70) A Convenient Route to Troponoids. R Noyori, S. Makino, and H. Takaya, Tetrahedron Lett., 1745 (1973).

(71) Reaction of $\alpha, \alpha^{\prime}$-Dibromo Ketones and Aromatic Olefins Promoted by Iron Carbonyl. A Cationic $3+2 \rightarrow 5$ Cycloaddition. R. Noyori, K. Yokoyama, and Y. Hayakawa, J. Am. Chem. Soc., 95, 2722 (1973).

(72) Iron Carbonyl Promoted Reaction of $\alpha, \alpha^{\prime}$-Dibromo Ketones and Carboxamides. A Convenient Route to Muscarines via Furanones. R. Noyori, Y. Hayakawa, S. Makino, N. Hayakawa, and H. Takaya, J. Am. Chem. Soc., 95, 4103 (1973).

(73) Reaction of 2,2-Diphenylmethylenecyclopropane with Electron-Deficient Quinoid Compounds. New $\left[\sigma^{2}+\pi^{2}+\pi^{2}\right]$-Type Cycloadditions. R. Noyori, N. Hayashi, and M. Katô, Tetrahedron Lett., 2983 (1973).

(74) Nickel(0)-Catalyzed Valence Isomerization of the 1,1'-Bishomocubane System. H. Takaya, M. Yamakawa, and R. Noyori, Chem. Lett., 781 (1973).

(75) The Nickel-Catalyzed Isomerization of Methylenecyclopropane to Butadiene. H. Takaya, N. Hayashi, T. Ishigami, and R. Noyori, Chem. Lett., 813 (1973).

(76) A New Route to Tropanes. R. Noyori, S. Makino, Y. Baba, and Y. Hayakawa, Tetrahedron Lett., 1049 (1974).

(77) Nickel(0) Catalyzed Cycloaddition of Bicyclo[2.1.0]pentane and Olefins. Contrasting Stereochemistry of the Thermal and Transition Metal Catalyzed Reactions. R. Noyori, Y. Kumagai, and H. Takaya, J. Am. Chem. Soc., 96, 634 (1974).

(78) Stereochemistry of the Nickel(0) Catalyzed Reaction of Bicyclo[1.1.0]butane and Electron-Deficient Olefins. $\quad$ R. Noyori, H. Kawauchi, and H. Takaya, Tetrahedron Lett., 1749 (1974).

(79) A New, General Synthesis of Tropane Alkaloids. R. Noyori, Y. Baba, and Y. Hayakawa, J. Am. Chem. Soc., 96, 3336 (1974).

(80) Photo-Induced Polar Addition of Protic Solvents to Cycloalkenones. Evidence for the Ground-State trans Isomers as Chemically-Reactive Intermediates. R. Noyori and M. Katô, Bull. Chem. Soc. Jpn., 47, 1460 (1974).

(81) The Stereoselective Reduction of Tropinone to Tropine. Y. Hayakawa and R. Noyori, Bull. Chem. Soc. Jpn., 47, 2617 (1974).

(82) Nickel(0) Catalyzed Reactions Involving Strained $\sigma$ Bonds. R. Noyori, In "Organotransition-Metal Chemistry", Y. Ishii and M. Tsutsui, Eds., Plenum Press, New York, 1975, p 231.

(83) Nickel(0)-Catalyzed Reaction of Quadricyclane with Electron-Deficient Olefins. R. Noyori, I. Umeda, H. Kawauchi, and H. Takaya, J. Am. Chem. Soc., 97, 812 (1975).

(84) Novel Photorearrangements of Cyclic Cross-Conjugated Dienones in Sulfuric Acid. Transformations Involving a Stereospecific Symmetry-Forbidden Process. R. Noyori, Y. Ohnishi, and M. Katô, J. Am. Chem. Soc., 97, 928 (1975). 
(85) A Method for the Generation of a Synthetic Equivalent of Unsubstituted Oxyallyl via the Bromo Ketone-Iron Carbonyl Reaction. A New Route to Thujaplicins. R. Noyori, S. Makino, T. Okita, and Y. Hayakawa, J. Org. Chem., 40, 806 (1975).

(86) A New Route to Nezukone. Y. Hayakawa, M. Sakai, and R. Noyori, Chem. Lett., 509 (1975).

(87) The Role of Nucleophilic Solvents in the Acid-Catalyzed Cyclization of a CrossConjugated Cycloalkadienone. $\quad$ R. Noyori, Y. Ohnishi, and M. Katô, Bull. Chem. Soc. Jpn., 48, 2881 (1975).

(88) Synthesis of Carbocamphenilone and Its 6,7-Dehydro Derivative. R. Noyori, T. Souchi, and Y. Hayakawa, J. Org. Chem., 40, 2681 (1975).

(89) Peri- and Regioselectivities of the Nickel(0)-Catalyzed Valence Isomerization of the 1,8Bishomocubane System. A Molecular Orbital Consideration. R. Noyori, M. Yamakawa, and H. Takaya, J. Am. Chem. Soc., 98, 1471 (1976).

(90) Stereochemistry of the Electrophilic Olefinic Substitution of 2-Oxyallyl-Iron(II) Species. Inspection of the Conformation of the Zwitterionic Intermediates. Y. Hayakawa, K. Yokoyama, and R. Noyori, Tetrahedron Lett., 4347 (1976).

(91) The Photochemical Reaction of Iron Pentacarbonyl and 1,3-Butadiene-1,1,4,4-d $d_{4}$. The Lack of Secondary Isotope Effects. R. Noyori and K. Yokoyama, Bull. Chem. Soc. Jpn., 49, 1723 (1976).

(92) Direct Observation of Dienol Intermediates in Photochemical Deconjugation of an $\alpha, \beta$ Unsaturated Ketone. Photoisomerization of 1-Acetylcyclooctene. R. Noyori, H. Inoue, and M. Katô, Bull. Chem. Soc. Jpn., 49, 3673 (1976).

(93) Fluoride Ion Catalyzed Aldol Reaction between Enol Silyl Ethers and Carbonyl Compounds. R. Noyori, K. Yokoyama, J. Sakata, I. Kuwajima, E. Nakamura, and M. Shimizu, J. Am. Chem. Soc., 99, 1265 (1977).

(94) Synthesis of 3(2H)-Furanones by the Iron Carbonyl-Promoted Cyclocoupling Reaction of $\alpha, \alpha^{\prime}$-Dibromo Ketones and Carboxamides. A Convenient Route to Muscarines. Y. Hayakawa, H. Takaya, S. Makino, N. Hayakawa, and R. Noyori, Bull. Chem. Soc. Jpn., 50, 1990 (1977).

(95) Photo-Induced Cycloaddition of 1-Nitrocyclooctene and Cyclopentadiene. K. Yokoyama, M. Katô, and R. Noyori, Bull. Chem. Soc. Jpn., 50, 2201 (1977).

(96) Regioselectivity of the Iron Carbonyl Promoted Cyclocoupling Reaction of $\alpha, \alpha$-Dibromo Ketones with Olefins and Dienes. R. Noyori, F. Shimizu, K. Fukuta, H. Takaya, and Y. Hayakawa, J. Am. Chem. Soc., 99, 5196 (1977).

(97) A Stereocontrolled General Synthesis of $C$-Nucleosides. T. Sato, Y. Hayakawa, and R. Noyori, Nucleic Acids Res. Spec. Publ. (3), 29 (1977).

(98) Iron Carbonyls in Organic Synthesis. R. Noyori, Ann. New York Acad. Sci., 295, 225 (1977).

(99) A Molecular Orbital Study of Silylated Carbenes. R. Noyori, M. Yamakawa, and W. Ando, Bull. Chem. Soc. Jpn., 51, 811 (1978).

(100) Reaction of $\alpha, \alpha^{\prime}$-Dibromo Ketones and Iron Carbonyls. Mechanistic Aspects. R. Noyori, Y. Hayakawa, H. Takaya, S. Murai, R. Kobayashi, and N. Sonoda, J. Am. Chem. Soc., 100, 1759 (1978).

(101) Reactions of Polybromo Ketones with 1,3-Dienes in the Presence of Iron Carbonyls. New $3+4 \rightarrow 7$ Cyclocoupling Reaction Forming 4-Cycloheptenones. H. Takaya, S. Makino, Y. Hayakawa, and R. Noyori, J. Am. Chem. Soc., 100, 1765 (1978).

(102) New Synthesis of Troponoid Compounds via the Iron Carbonyl Promoted Cyclocoupling between Polybromo Ketones and 1,3-Dienes. H. Takaya, Y. Hayakawa, S. Makino, and R. Noyori, J. Am. Chem. Soc., 100, 1778 (1978). 
(103) General Synthesis of Tropane Alkaloids via the Polybromo Ketone-Iron Carbonyl Reaction. Y. Hayakawa, Y. Baba, S. Makino, and R. Noyori, J. Am. Chem. Soc., 100, 1786 (1978).

(104) Iron Carbonyl Promoted Reaction of $\alpha, \alpha^{\prime}$-Dibromo Ketones and Aromatic Olefins Leading to 3-Arylcyclopentanones. The [3 +2$]$ Cycloaddition Involving an Allylic Cation. Y. Hayakawa, K. Yokoyama, and R. Noyori, J. Am. Chem. Soc., 100, 1791 (1978).

(105) Novel Cyclopentenone Synthesis via the Iron Carbonyl Aided Cyclocoupling between $\alpha, \alpha$-Dibromo Ketones and Enamines. Y. Hayakawa, K. Yokoyama, and R. Noyori, J. Am. Chem. Soc., 100, 1799 (1978).

(106) A Single-Step Synthesis of $( \pm)-\alpha$-Cuparenone. Y. Hayakawa, F. Shimizu, and R. Noyori, Tetrahedron Lett., 993 (1978).

(107) A Stereocontrolled General Synthesis of C-Nucleosides. R. Noyori, T. Sato, and Y. Hayakawa, J. Am. Chem. Soc., 100, 2561 (1978).

(108) Cyclopentenones from $\alpha, \alpha^{\prime}$-Dibromoketones and Enamines: 2,5-Dimethyl-3-phenyl-2cyclopenten-1-one. R. Noyori, K. Yokoyama, and Y. Hayakawa, Org. Synth., 58, 56 (1978).

(109) Stereocontrolled Synthesis of Showdomycin and 6-Azapseudouridines. T. Sato, R. Ito, Y. Hayakawa, and R. Noyori, Tetrahedron Lett., 1829 (1978).

(110) Iron Carbonyl Promoted Reaction of $\alpha, \alpha^{\prime}$-Dibromo Ketones and Isobutylene, an Ene Reaction Involving Allylic Cations. R. Noyori, F. Shimizu, and Y. Hayakawa, Tetrahedron Lett., 2091 (1978).

(111) Organic Synthesis Using Metal Carbonyls. R. Noyori, Kagaku Sosetsu, 19, 139 (1978).

(112) Nickel(0) Catalyzed Reaction of Bicyclo[1.1.0]butanes with Electron-Deficient Olefins. H. Takaya, M. Yamakawa, and R. Noyori, In "Fundamental Research in Homogeneous Catalysis", Vol. 2, Y. Ishii and M. Tsutsui, Eds., Plenum Press, New York, 1978, p 221.

(113) The Use of Zinc/Silver Couple in the Cyclocoupling Reaction of Polybromo Ketones and Furan. T. Sato and R. Noyori, Bull. Chem., Soc. Jpn., 51, 2745 (1978).

(114) Synthesis of Pseudouridines Modified at the C-5' Position. T. Sato, M. Watanabe, and R. Noyori, Tetrahedron Lett., 4403 (1978).

(115) Synthesis of Novel Pyrimidine C-Nucleosides. T. Sato and R. Noyori, Nucleic Acids Research, Special Publication No. 5, 257 (1978).

(116) Evidence for a Trimethylenemethane Complex Intermediate in the Nickel(0) Catalyzed Reaction of Methylenecyclopropane. R. Noyori, M. Yamakawa, and H. Takaya, Tetrahedron Lett., 4823 (1978).

(117) A Convenient Route to 5'-Modified Pseudoisocytidines and 2-Thiopseudouridines. T. Sato, M. Watanabe, and R. Noyori, Chem. Lett., 1297 (1978).

(118) Nickel(0) Catalyzed Reactions of Strained Ring Systems. R. Noyori, In "Inorganic Compounds with Unusual Properties-II", (Adv. Chem. Ser. Vol. 173), R. B. King, Ed., American Chemical Society, Washington, D. C., 1979, p 307.

(119) Organic Syntheses via the Polybromo Ketone-Iron Carbonyl Reaction. R. Noyori Acc. Chem. Res., 12, 61 (1979).

(120) Intramolecular Dibromo Ketone-Iron Carbonyl Reaction in Terpene Synthesis. R. Noyori, M. Nishizawa, F. Shimizu, Y. Hayakawa, K. Maruoka, S. Hashimoto, H. Yamamoto, and H. Nozaki, J. Am. Chem. Soc., 101, 220 (1979).

(121) Palladium(0) Catalyzed Reaction of 1,3-Diene Epoxides. A Useful Method for the SiteSpecific Oxygenation of 1,3-Dienes. M. Suzuki, Y. Oda, and R. Noyori, J. Am. Chem. Soc., 101, 1623 (1979).

(122) A New Method for Converting Oxiranes to Allylic Alcohols by an Organosilicon Reagent. S. Murata, M. Suzuki, and R. Noyori, J. Am. Chem. Soc., 101, 2738 (1979). 
(123) Virtually Complete Enantioface Differentiation in Carbonyl Group Reduction by a Complex Aluminum Hydride Reagent. R. Noyori, I. Tomino, and Y. Tanimoto, J. Am. Chem. Soc., 101, 3129 (1979).

(124) A Stereocontrolled Synthesis of C-4' Alkylated Pyrimidine C-Nucleosides. T. Sato, M. Watanabe, and R. Noyori, Tetrahedron Lett., 2897 (1979).

(125) ${ }^{17}$ O NMR Chemical Shifts Versus Structure Relationships in Oxiranes. H. Iwamura, T. Sugawara, Y. Kawada, K. Tori, R. Muneyuki, and R. Noyori, Tetrahedron Lett., 3449 (1979).

(126) A General, Stereocontrolled Entry to Pyrimidine Homo-C-Nucleosides. T. Sato, K. Marunouchi, and R. Noyori, Tetrahedron Lett., 3669 (1979).

(127) The Stereocontrolled Synthesis of Homo-C-Nucleosides. T. Sato and R. Noyori, Nucleic Acids Symp. Ser., (6), 19 (1979).

(128) A Highly Efficient Synthesis of Prostaglandin Intermediates Possessing the 15S Configuration. $\quad$ R. Noyori, I. Tomino, and M. Nishizawa, J. Am. Chem. Soc., 101, 5843 (1979).

(129) Reaction of Acetals and Trialkylsilanes Catalyzed by Trimethylsilyl Trifluoromethanesulfonate. A Simple Method for Conversion of Acetals to Ethers. T. Tsunoda, M. Suzuki, and R. Noyori, Tetrahedron Lett., 4679 (1979).

(130) Synthesis of Homoshowdomycin and Homopyrazomycin. T. Sato and R. Noyori, Heterocycles, 13, 141 (1979).

(131) Trimethylsilyl Trifluoromethanesulfonate as a Catalyst of the Reaction of Allyltrimethylsilane and Acetals. T. Tsunoda, M. Suzuki, and R. Noyori, Tetrahedron Lett., 21, 71 (1980).

(132) Silylation with a Perfluorinated Resinsulfonic Acid Trimethylsilyl Ester. S. Murata and R. Noyori, Tetrahedron Lett., 21, 767 (1980).

(133) Tris(dialkylamino)sulfonium Enolates. R. Noyori, I. Nishida, J. Sakata, and M. Nishizawa, J. Am. Chem. Soc., 102, 1223 (1980).

(134) Palladium(0)-Catalyzed Reaction of $\alpha, \beta$-Epoxy Ketones Leading to $\beta$-Diketones. $M$. Suzuki, A. Watanabe, and R. Noyori, J. Am. Chem. Soc., 102, 2095 (1980).

(135) Organocopper Conjugate Addition Revisited. M. Suzuki, T. Suzuki, T. Kawagishi, and R. Noyori, Tetrahedron Lett., 21, 1247 (1980).

(136) A Facile Procedure for Acetalization under Aprotic Conditions. T. Tsunoda, M. Suzuki, and R. Noyori, Tetrahedron Lett., 21, 1357 (1980).

(137) Synthesis of 3-Carbamoyl-4-[( $\beta$-D-ribofuranosyl)methyl]pyrazole, a Pyrazole Homo-Cnucleoside. $\quad$ T. Sato and R. Noyori, Bull. Chem. Soc. Jpn., 53, 1195 (1980).

(138) A Stereoselective Aldol-Type Condensation of Enol Silyl Ethers and Acetals Catalyzed by Trimethylsilyl Trifluoromethanesulfonate. S. Murata, M. Suzuki, and R Noyori, J. Am. Chem. Soc., 102, 3248 (1980).

(139) Synthesis of 4'-Phenylated Pyrimidine C-Nucleosides. T. Sato, M. Watanabe, and R. Noyori, Heterocycles, 14, 761 (1980).

(140) Stereocontrolled Synthesis of 1',4'-Dialkylated Pyrimidine Ribo- $C$-nucleosides. T. Sato, M. Watanabe, and R. Noyori, Chem. Lett., 679 (1980).

(141) Synthesis of 2'-Methylated Pyrimidine C-Nucleosides. T. Sato, H. Kobayashi, and R. Noyori, Tetrahedron Lett., 21, 1971 (1980).

(142) Alkylation via Tris(dialkylamino)sulfonium Enolates. R. Noyori, I. Nishida, and J. Sakata Tetrahedron Lett., 21, 2085 (1980).

(143) Condensation of Enol Silyl Ethers and Dialkoxymethanes Catalyzed by Trimethylsilyl Trifluoromethanesulfonate. Regiospecific Synthesis of $\alpha$-Alkoxymethyl Ketones. S. Murata, M. Suzuki, and R. Noyori, Tetrahedron Lett., 21, 2527 (1980).

(144) Synthesis of 4'-Hydroxymethylated Pyrimidine Ribo-C-nucleosides. T. Sato and R. Noyori, Tetrahedron Lett., 21, 2535 (1980). 
(145) Remote Substituent Effects in the Baeyer-Villiger Oxidation. I. Through-Bond $\gamma$ Substituent Effect on the Regioselectivity. R. Noyori, T. Sato, and H. Kobayashi, Tetrahedron Lett., 21, 2569 (1980).

(146) Remote Substituent Effects in the Baeyer-Villiger Oxidation. II. Regioselection Based on the Hydroxyl Group Orientation in the Tetrahedral Intermediate. R. Noyori, H. Kobayashi, and T. Sato, Tetrahedron Lett., 21, 2573 (1980).

(147) Asymmetric Synthesis of Chiral Geraniol-1-d and Related Terpenic Alcohols. M. Nishizawa and R. Noyori, Tetrahedron Lett., 21, 2821 (1980).

(148) A Molecular Orbital Study of Carbomethoxycarbene and Dicarboxycarbene. R. Noyori and M. Yamakawa, Tetrahedron Lett., 21, 2851 (1980).

(149) Conformationally Selective Transannular Cyclizations of Humulene 9,10-Epoxide. Synthesis of the Two Skeletally Different Cyclohumulanoids: DL-Bicyclohumulenone and DL-Africanol. H. Shirahama, K. Hayano, Y. Kanemoto, S. Misumi, T. Ohtsuka, N. Hashiba, A. Furusaki, S. Murata, R. Noyori, and T. Matsumoto, Tetrahedron Lett., 21, 4835 (1980).

(150) Synthesis of 2,2'-Bis(diphenylphosphino)-1,1'-binaphthyl (BINAP), an Atropisomeric Chiral Bis(triaryl)phosphine, and Its Use in the Rhodium(I)-Catalyzed Asymmetric Hydrogenation of $\alpha$-(Acylamino)acrylic Acids. A. Miyashita, A. Yasuda, H. Takaya, K. Toriumi, T. Ito, T. Souchi, and R. Noyori, J. Am. Chem. Soc., 102, 7932 (1980).

(151) Stereocontrolled Entry to Pyrimidine Hamamelo- $C$-nucleosides. T. Sato, H. Kobayashi, and R. Noyori, Heterocycles, 15, 321 (1981).

(152) Highly Enantioselective Reduction of Alkynyl Ketones by a Binaphthol-Modified Aluminum Hydride Reagent. Asymmetric Synthesis of Some Insect Pheromones. M. Nishizawa, M. Yamada, and R. Noyori, Tetrahedron Lett., 22, 247 (1981).

(153) New Methodologies Related to Prostaglandin Synthesis. R. Noyori, In "(IUPAC) Organic Synthesis-Today and Tomorrow", B. M. Trost and C. R. Hutchinson, Eds., Pergamon Press, Oxford, 1981, p 273.

(154) A New Procedure for $\alpha$-Alkoxyalkylation of $\alpha, \beta$-Unsaturated Ketones. M. Suzuki, T. Kawagishi, and R. Noyori, Tetrahedron Lett., 22, 1809 (1981).

(155) Erythro-Selective Aldol Reaction via Tris(dialkylamino)sulfonium Enolates. R. Noyori, I. Nishida, and J. Sakata, J. Am. Chem. Soc., 103, 2106 (1981).

(156) A Facile Procedure for O-Tritylation. S. Murata and R. Noyori, Tetrahedron Lett., 22, 2107 (1981).

(157) A Cationic [3,4] Sigmatropic Rearrangement. M. Nishizawa and R. Noyori, Bull. Chem. Soc. Jpn., 54, 2233 (1981).

(158) Nickel(0)-Catalyzed Reactions of Bicyclo[2.1.0]pentane and Electron-Deficient Olefins. H. Takaya, T. Suzuki, Y. Kumagai, M. Yamakawa, and R. Noyori, J. Org. Chem., 46, $2846(1981)$.

(159) Nickel(0)-Catalyzed Reactions of Bicyclo[1.1.0]butanes. Geminal Two-Bond Cleavage Reaction and the Stereospecific Olefin Trapping of the Carbenoid Intermediate. $\mathrm{H}$. Takaya, T. Suzuki, Y. Kumagai, M. Hosoya, H. Kawauchi, and R. Noyori, J. Org. Chem., 46, 2854 (1981).

(160) A Tris(dialkylamino)sulfonium Phenoxide. R. Noyori, I. Nishida, and J. Sakata, Tetrahedron Lett., 22, 3993 (1981).

(161) Palladium(0) Catalyzed Reaction of 1,4-Epiperoxides. Conversion of a Prostaglandin Endoperoxide to Primary Prostaglandins. M. Suzuki, R. Noyori, and N. Hamanaka, J. Am. Chem. Soc., 103, 5606 (1981).

(162) Palladium(0) Catalyzed Reaction of 1,3-Diene 1,4-Epiperoxides. M. Suzuki, Y. Oda, and R. Noyori, Tetrahedron Lett., 22, 4413 (1981). 
(163) Asymmetric Synthesis via Axially Dissymmetric Molecules. A Binaphthol-Modified Complex Aluminum Hydride Reagent Possessing Extremely High Ability of Chiral Recognition. R. Noyori, Pure Appl. Chem., 53, 2315 (1981).

(164) Trimethysilyl Triflate in Organic Synthesis. R. Noyori, S. Murata, and M. Suzuki, Tetrahedron (Tetrahedron Symposium-In-Print, E. J. Corey, Ed.), 37, 3899 (1981).

(165) Novel Packing Material for Optical Resolution: (+)-Poly(triphenylmethyl methacrylate) Coated on Macroporous Silica Gel. Y. Okamoto, S. Honda, I. Okamoto, H. Yuki, S. Murata, R. Noyori, and H. Takaya, J. Am. Chem. Soc., 103, 6971 (1981).

(166) Ring Opening of Oxiranes by Trimethylsilyl Trifluoromethanesulfonate. S. Murata, M. Suzuki, and R. Noyori, Bull. Chem. Soc. Jpn., 55, 247 (1982).

(167) Bis(trimethylsilyl) Peroxide for the Baeyer-Villiger Type Oxidation. M. Suzuki, H. Takada, and R. Noyori, J. Org. Chem., 47, 902 (1982).

(168) Rhodium(I) Catalyzed Enantioselective Hydrogen Migration of Prochiral Allylamines. K. Tani, T. Yamagata, S. Otsuka, S. Akutagawa, H. Kumobayashi, T. Taketomi, H. Takaya, A. Miyashita, and R. Noyori, In "Asymmetric Reactions and Processes in Chemistry", Adv. Chem. Ser. Vol. 185, E. L. Eliel and S. Otsuka, Eds., American Chemical Society, Washington, D. C., 1982, p 187.

(169) 2,2'-Bis(diphenylphosphino)-1,1'-binaphthyl: A New Axially Dissymmetric Bis(triaryl)phosphine. A. Miyashita, H. Takaya, and R. Noyori, In "Asymmetric Reactions and Processes in Chemistry", Adv. Chem. Ser. Vol. 185, American Chemical Society, Washington, D. C., 1982, p 274.

(170) Nickel(0) Catalyzed [2 + 2] Cross-Addition of Bicyclo[2.2.1]heptene Derivatives with Electron-Deficient Olefins. H. Takaya, M. Yamakawa, and R. Noyori, Bull. Chem. Soc. Jpn., 55, 852 (1982).

(171) Structure and Absolute Configuration of [(+) $589-(R)-2,2$ '-Bis(diphenylphosphino)-1,1'binaphthyl](8,9,10-trinorborna-2,5-diene)rhodium(I) Perchlorate, the Precursor of a Catalyst for Highly Enantioselective Hydrogenations. K. Toriumi, T. Ito, H. Takaya, T. Souchi, and R. Noyori, Acta Cryst., B38, 807 (1982).

(172) Condensation of Enol Silyl Ethers with 2-Acetoxytetrahydrofuran and -tetrahydropyrans. S. Murata and R. Noyori, Tetrahedron Lett., 23, 2601 (1982).

(173) Ruthenium(II)-Catalyzed Reaction of 1,4-Epiperoxides. M. Suzuki, R. Noyori, and N. Hamanaka, J. Am. Chem. Soc., 104, 2024 (1982).

(174) Cationic Rhodium(I) Complex-Catalysed Asymmetric Isomerisation of Allylamines to Optically Active Enamines. K. Tani, T. Yamagata, S. Otsuka, S. Akutagawa, H. Kumobayashi, T. Taketomi, H. Takaya, A. Miyashita, and R. Noyori, J. Chem. Soc., Chem. Commun., 600 (1982).

(175) Preparation and Structure of $(R)-(-)-$ and $(S)-(+)-2,2 '-(2,2-D i m e t h y l-2-$ silapropane-1,3diyl)-1,1'-binaphthalene. R. Noyori, N. Sano, S. Murata, Y. Okamoto, H. Yuki, and T. Ito, Tetrahedron Lett., 23, 2969 (1982).

(176) Regiospecific $\alpha$-Dialkoxymethylation of Preformed Enolates. M. Suzuki, A. Yanagisawa, and R. Noyori, Tetrahedron Lett., 23, 3595 (1982).

(177) Trimethylsilyl Triflate Induced Reaction of Humulene 6,7-Epoxide. Cyclization to 5Hydroxy-4,8,11,11-tetramethyltricyclo[6.3.0.02,4]undec-9-ene. H. Shirahama, S. Murata, T. Fujita, B. R. Chhabra, R. Noyori, and T. Matsumoto, Bull. Chem. Soc. Jpn., 55, 2691 (1982).

(178) A Facile Synthesis of (-)-Prostaglandin $E_{1}$ via a Three-Component Coupling Process. M. Suzuki, T. Kawagishi, T. Suzuki, and R. Noyori, Tetrahedron Lett., 23, 4057 (1982).

(179) A New Phosphorylation Method for the Nucleotide Synthesis. Y. Hayakawa, Y. Aso, M. Uchiyama, and R. Noyori, Nucleic Acids Symp. Ser., (11), 65 (1982).

(180) Synthesis of a Pyrazole Prostacyclin. M. Suzuki, S. Sugiura, and R. Noyori, Tetrahedron Lett., 23, 4817 (1982). 
(181) A General Synthesis of Primary Prostaglandins. M. Suzuki, T. Kawagishi, and R. Noyori, Tetrahedron Lett., 23, 5563 (1982).

(182) Facile Nucleoside Phosphorylation via Hydroxyl Activation. Y. Hayakawa, Y. Aso, M. Uchiyama, and R. Noyori, Tetrahedron Lett., 24, 1165 (1983).

(183) A Short Way to Prostacyclin. M. Suzuki, A. Yanagisawa, and R. Noyori, Tetrahedron Lett., 24, 1187 (1983).

(184) Tris(dialkylamino)sulfonium Enolates. Synthesis, Structure, and Reactions. R. Noyori, I. Nishida, and J. Sakata, J. Am. Chem. Soc., 105, 1598 (1983).

(185) Fluoride Ion Catalyzed Aldol Reaction between Enol Silyl Ethers and Carbonyl Compounds. E. Nakamura, M. Shimizu, I. Kuwajima, J. Sakata, K. Yokoyama, and R. Noyori, J. Org. Chem., 48, 932 (1983).

(186) The Baeyer-Villiger Oxidation of 8-Oxabicyclo[3.2.1]octan-3-ones. Substituent Effects on the Regioselectivity. R. Noyori, T. Sato, and H. Kobayashi, Bull. Chem. Soc. Jpn., 56, 2661 (1983).

(187) Stereocontrolled General Synthesis of Pyrimidine C-Nucleosides Having Branched-Chain Sugar Moieties. T. Sato, M. Watanabe, H. Kobayashi, and R. Noyori, Bull. Chem. Soc. Jpn., 56, 2680 (1983).

(188) General Synthesis of Homo-C-nucleosides. T. Sato and R. Noyori, Bull. Chem. Soc. Jpn., 56, 2700 (1983).

(189) A Short Synthesis of (-)-Prostaglandin $E_{1}$. T. Tanaka, T. Toru, N. Okamura, A. Hazato, S. Sugiura, K. Manabe, S. Kurozumi, M. Suzuki, T. Kawagishi, and R. Noyori, Tetrahedron Lett., 24, 4103 (1983).

(190) Chemoselective Phosphorylation of $N$-Unblocked Nucleosides. Y. Hayakawa, Y. Aso, M. Uchiyama, and R. Noyori, Nucleic Acids Symp. Ser., (12), 47 (1983).

(191) Tris(dialkylamino)sulfonium Enolates and Phenoxide. R. Noyori, In "Selectivity-A Goal for Synthetic Efficiency", W. Bartmann and B. M. Trost, Eds., Verlag Chemie, Weinheim, 1984, p 121.

(192) Chemoselective Phosphorylation of $N$-Unprotected Nucleosides via Aluminum Alkoxides. Y. Hayakawa, Y. Aso, M. Uchiyama, and R. Noyori, Tetrahedron Lett., 24, 5641 (1983).

(193) Glycosylation Using Glucopyranosyl Fluorides and Silicon-Based Catalysts. Solvent Dependency of the Stereoselection. S. Hashimoto, M. Hayashi, and R. Noyori, Tetrahedron Lett., 25, 1379 (1984).

(194) Synthesis of Prostaglandin $D_{1}$ and $D_{2}$ via the Three-Component Coupling Process. M. Suzuki, A. Yanagisawa, and R. Noyori, Tetrahedron Lett., 25, 1383 (1984).

(195) An Easy Preparation of Triphenylmethyl Carboxylates. S. Hashimoto, M. Hayashi, and R. Noyori, Bull. Chem. Soc. Jpn., 57, 1431 (1984).

(196) 2,2'-Bis(diphenylphosphino)-1,1'-binaphthyl (BINAP), A New Atropisomeric Bis(triaryl)phosphine. Synthesis and Its Use in the Rh(I)-Catalyzed Asymmetric Hydrogenation of $\alpha$-(Acylamino)acrylic Acids. A. Miyashita, H. Takaya, T. Souchi, and R. Noyori, Tetrahedron (Tetrahedron Symposium-In-Print, A. I. Meyers, Ed.), 40, 1245 (1984).

(197) Conjugate Addition of Phosphine-Complexed Organocopper Reagents to $\alpha, \beta$ Unsaturated Ketones. M. Suzuki, T. Suzuki, T. Kawagishi, Y. Morita, and R. Noyori, Isr. J. Chem., 24, 118 (1984).

(198) A Stereocontrolled Total Synthesis of $C$-Nucleosides. T. Sato, Y. Hayakawa, and R. Noyori, Bull. Chem. Soc. Jpn., 57, 2515 (1984).

(199) Highly Enantioselective Isomerization of Prochiral Allylamines Catalyzed by Chiral Diphosphine Rhodium(I) Complexes. Preparation of Optically Active Enamines. K. Tani, T. Yamagata, S. Akutagawa, H. Kumobayashi, T. Taketomi, H. Takaya, A. Miyashita, R. Noyori, and S. Otsuka, J. Am. Chem. Soc., 106, 5208 (1984). 
(200) A Convenient Method for the Formation of Internucleotide Linkage. Y. Hayakawa, M. Uchiyama, and R. Noyori, Tetrahedron Lett., 25, 4003 (1984).

(201) Simple Synthesis of Glycosyl Fluorides. M. Hayashi, S. Hashimoto, and R. Noyori, Chem. Lett., 1747 (1984).

(202) A Convenient Synthesis of Adenlyl-(2' $\left.\rightarrow 5^{\prime}\right)$-adenylyl-(2' $\left.\rightarrow 5^{\prime}\right)$-adenosine (2-5A Core). Y. Hayakawa, M. Uchiyama, T. Nobori, and R. Noyori, Nucleic Acids Symp. Ser., (15), 85 (1984).

(203) Short Synthesis of 6-Oxoprostaglandin $E_{1}$ and 6-Oxoprostaglandin $F_{1 \alpha}$. T. Tanaka, A. Hazato, K. Bannai, N. Okamura, S. Sugiura, K. Manabe, S. Kurozumi, M. Suzuki, and R. Noyori, Tetrahedron Lett., 25, 4947 (1984).

(204) Toward Highly Enantioselective Reduction. R. Noyori, In "New Frontiers in Organometallic and Inorganic Chemistry", H. Yaozeng, A. Yamamoto, and B.-K. Teo, Eds., Science Press, Beijing, 1984, p 159.

(205) Synthesis of New Antineoplastic Prostaglandins. S. Sugiura, T. Toru, T. Tanaka, A. Hazato, N. Okamura, K. Bannai, K. Manabe, S. Kurozumi, and R. Noyori, Chem. Pharm. Bull., 32, 4658 (1984).

(206) Rational Designing of Efficient Chiral Reducing Agents. Highly Enantioselective Reduction of Aromatic Ketones by Binaphthol-Modified Lithium Aluminum Hydride Reagents. R. Noyori, I. Tomino, Y. Tanimoto, and M. Nishizawa, J. Am. Chem. Soc., 106, 6709 (1984).

(207) Synthetic Applications of the Enantioselective Reduction by Binaphthol-Modified Lithium Aluminum Hydride Reagents. R. Noyori, I. Tomino, M. Yamada, and M. Nishizawa, J. Am. Chem. Soc., 106, 6717 (1984).

(208) Prostaglandin-Synthesen durch Dreikomponenten-Kupplung. R. Noyori und M. Suzuki, Angew. Chem., 96, 854 (1984); Prostaglandin Syntheses by Three-Component Coupling. R. Noyori and M. Suzuki, Angew. Chem., Int. Ed. Engl., 23, 847 (1984).

(209) A Convenient Synthesis of 2'-5' Linked Oligoribonucleotides. Y. Hayakawa, M. Uchiyama, T. Nobori, and R. Noyori, Tetrahedron Lett., 26, 761 (1985).

(210) Novel Nucleophilic Substitution Reaction by Radical Cation Intermediates. Photosensitized Transacetalization via $\mathrm{S}_{\mathrm{ON}} 1 \mathrm{Mechanism.} \mathrm{S.} \mathrm{Hashimoto,} \mathrm{I.} \mathrm{Kurimoto,} \mathrm{Y.}$ Fujii, and R. Noyori, J. Am. Chem. Soc., 107, 1427 (1985).

(211) An Extremely Short Way to Prostaglandins. M. Suzuki, A. Yanagisawa, and R. Noyori, J. Am. Chem. Soc., 107, 3348 (1985).

(212) Selectivity in Silicon-Mediated Organic Reactions: Origin and Application. R. Noyori, M. Hayashi, and S. Hashimoto, In "Organosilicon and Bioorganosilicon Chemistry: Structure, Bonding, Reactivity and Synthetic Application", H. Sakurai, Ed., Ellis Horwood, West Sussex, 1985, p 213.

(213) Asymmetric Hydrogenation of Geraniol and Nerol Catalyzed by BINAP-Rhodium(I) Complexes. S. Inoue, M. Osada, K. Koyano, H. Takaya, and R. Noyori, Chem. Lett., 1007 (1985).

(214) Binaphthyls: The Beauty and Chiral Uses. R. Noyori and H. Takaya, Chemica Scripta, 25, 83 (1985).

(215) Synthesis of New Antineoplastic Alkylidenecyclopentenones. S. Sugiura, A. Hazato, T. Tanaka, N. Okamura, K. Bannai, K. Manabe, S. Kurozumi, M. Suzuki, and R. Noyori, Chem. Pharm. Bull., 33, 4120 (1985).

(216) Synthesis of 2'-End-modified 2'-5'-Oligoadenylates. Y. Hayakawa, T. Nobori, and R. Noyori, Nucleic Acids Symp. Ser., (16), 129 (1985).

(217) A Convenient Method for the Oxidation of Nucleoside Phosphites to Phosphates. Y. Hayakawa, M. Uchiyama, and R. Noyori, Nucleic Acids Symp. Ser., (16), 145 (1985).

(218) Allyl Protection of Internucleotide Linkage. Y. Hayakawa, M. Uchiyama, H. Kato, and R. Noyori, Tetrahedron Lett., 26, 6505 (1985). 
(219) Convergent Synthesis of Prostaglandins. R. Noyori and M. Suzuki, In "Advances in Prostaglandin, Thromboxane, and Leukotriene Research", Vol. 15, O. Hayaishi and S. Yamamoto, Eds., Raven Press, New York, 1985, p 295.

(220) Three-Component Coupling Process to Synthesize Prostaglandin Analogues of Pharmacological Interest. S. Kurozumi, T. Tanaka, N. Okamura, K. Bannai, A. Hazato, S. Sugiura, K. Manabe, and R. Noyori, In "Advances in Prostaglandin, Thromboxane, and Leukotriene Research", Vol. 15, O. Hayaishi and S. Yamamoto, Eds., Raven Press, New York, 1985, p 299.

(221) Natural Product Synthesis via the Polybromo Ketone-Iron Carbonyl Reaction. R. Noyori and Y. Hayakawa, (Tetrahedron Symposium-In-Print, M. F. Semmelhack, Ed.), Tetrahedron, 41, 5879 (1985).

(222) Practical Synthesis of $(R)$ - or $(S)-2,2$ '-Bis(diarylphosphino)-1,1'-binaphthyls (BINAPs). H. Takaya, K. Mashima, K. Koyano, M. Yagi, H. Kumobayashi, T. Taketomi, S. Akutagawa, and R. Noyori, J. Org. Chem., 51, 629 (1986)

(223) Pseudouridine, Pseudoisocytidine, and 2-Thiopseudouridine. A General Synthesis of Pyrimidine C-Nucleosides. T. Sato, Y. Hayakawa, and R. Noyori, In "Nucleic Acid Chemistry", Part 3, L. B. Townsend and R. S. Tipson, Eds., John Wiley \& Sons, New York, 1986, p 81.

(224) Allyloxycarbonyl Group: A Versatile Blocking Group for Nucleotide Synthesis. Y. Hayakawa, H. Kato, M. Uchiyama, H. Kajino, and R. Noyori, J. Org. Chem., 51, 2400 (1986).

(225) Synthesis of (7E)- and (7Z)-Punaglandin 4. Structural Revision. M. Suzuki, Y. Morita, A. Yanagisawa, R. Noyori, B. J. Baker, and P. J. Scheuer, J. Am. Chem. Soc., 108, 5021 (1986).

(226) Nonaqueous Oxidation of Nucleoside Phosphites to the Phosphates. Y. Hayakawa, M. Uchiyama, and R. Noyori, Tetrahedron Lett., 27, 4191 (1986).

(227) Solid-Phase Synthesis of Oligodeoxyribonucleotides Using the Bis(trimethylsilyl)peroxide Oxidation of Phosphites. Y. Hayakawa, M. Uchiyama, and R. Noyori, Tetrahedron Lett., 27, 4195 (1986).

(228) Antitumor Activity of $\Delta^{7}$-Prostaglandin $A_{1}$ and $\Delta^{12}$-Prostaglandin $\mathrm{J}_{2}$ in Vitro and in Vivo. T. Kato, M. Fukushima, S. Kurozumi, and R. Noyori, Cancer Res., 46, 3538 (1986).

(229) Catalytic Asymmetric Induction. Highly Enantioselective Addition of Dialkylzincs to Aldehydes. M. Kitamura, S. Suga, K. Kawai, and R. Noyori, J. Am. Chem. Soc., 108, 6071 (1986).

(230) Asymmetric Synthesis of Isoquinoline Alkaloids by Homogeneous Catalysis. R. Noyori, M. Ohta, Yi Hsiao, M. Kitamura, T. Ohta, and H. Takaya, J. Am. Chem. Soc., 108, 7117 (1986).

(231) Photoinduced Transacetalization using a Tris(bipyridine)ruthenium(II)-Methyl Viologen Cosensitizing System. R. Noyori and I. Kurimoto, J. Chem. Soc., Chem. Commun., 1425 (1986).

(232) Electrochemical Glycosylation Method. R. Noyori and I. Kurimoto, J. Org. Chem., 51, 4320 (1986).

(233) Condensation of 1-Fluorofuranoses and Silylated Nucleobases Catalyzed by Tetrafluorosilane. R. Noyori and M. Hayashi, Chem. Lett., 57 (1987).

(234) $\beta$-D-Xylosides and their Analogues as Artificial Initiators of Glycosaminoglycan Chain Synthesis. M. Sobue, H. Habuchi, K. Ito, H. Yonekura, K. Oguri, K. Sakurai, S. Kamohara, Y. Ueno, R. Noyori, and S. Suzuki, Biochem. J., 241, 591 (1987).

(235) Enantioselective Hydrogenation of Allylic and Homoallylic Alcohols. H. Takaya, T. Ohta, N. Sayo, H. Kumobayashi, S. Akutagawa, S. Inoue, I. Kasahara, and R. Noyori, J. Am. Chem. Soc., 109, 1596 (1987). 
(236) Nitro-Olefin Trapping Reaction of Enolates In Situ Generated by Conjugate Addition Reaction: Short Syntheses of $\mathrm{PGE}_{1}, 6-\mathrm{Oxo}_{-} \mathrm{PGE}_{1}, 6-\mathrm{Oxo}_{-} \mathrm{PGF}_{1 \alpha}$, and $\mathrm{PGI}_{2}$. T. Tanaka, A. Hazato, K. Bannai, N. Okamura, S. Sugiura, K. Manabe, T. Toru, S. Kurozumi, M. Suzuki, T. Kawagishi, and R. Noyori, Tetrahedron, 43, 813 (1987).

(237) A General Approach to Nucleoside 3'- and 5'-Monophosphates. Y. Hayakawa, S. Wakabayashi, T. Nobori, and R. Noyori, Tetrahedron Lett., 28, 2259 (1987).

(238) Synthesis of 2'-5', 3'-5' Linked Triadenylates. Y. Hayakawa, T. Nobori, R. Noyori, and J. Imai, Tetrahedron Lett., 28, 2623 (1987).

(239) Asymmetric Hydrogenation of Unsaturated Carboxylic Acids Catalyzed by BINAPRuthenium(II) Complexes. T. Ohta, H. Takaya, M. Kitamura, K. Nagai, and R. Noyori, J. Org. Chem., 52, 3174 (1987).

(240) Asymmetric Hydrogenation of $\beta$-Keto Carboxylic Ester. A Practical, Purely Chemical Access to $\beta$-Hydroxy Esters in High Enantiomeric Purity. R. Noyori, T. Ohkuma, M. Kitamura, H. Takaya, N. Sayo, H. Kumobayashi, and S. Akutagawa, J. Am. Chem. Soc., 109, 5856 (1987).

(241) Kinetic Resolution of 4-Hydroxy-2-cyclopentenone by Rhodium-Catalyzed Asymmetric Isomerization. M. Kitamura, K. Manabe, R. Noyori, and H. Takaya, Tetrahedron Lett., 28, 4719 (1987).

(242) General Asymmetric Synthesis of Benzomorphans and Morphinans via Enantioselective Hydrogenation. M. Kitamura, Yi Hsiao, R. Noyori, and H. Takaya, Tetrahedron Lett., 28, 4829 (1987).

(243) A Controlled Synthesis of Isocarbacyclin. M. Suzuki, H. Koyano, and R. Noyori, J. Org. Chem., 52, 5583 (1987).

(244) Homogeneous Asymmetric Hydrogenation of Functionalized Ketones. M. Kitamura, T. Ohkuma, S. Inoue, N. Sayo, H. Kumobayashi, S. Akutagawa, T. Ohta, H. Takaya, and R. Noyori, J. Am. Chem. Soc., 110, 629 (1988).

(245) Synthesis and Structural Revision of (7E)- and (7Z)-Punaglandin 4. M. Suzuki, Y. Morita, A. Yanagisawa, B. J. Baker, P. J. Scheuer, and R. Noyori, J. Org. Chem., 53, 286 (1988).

(246) Kinetic Resolution of Racemic Allylic Alcohols by BINAP-Ruthenium(II)-Catalyzed Hydrogenation. M. Kitamura, I. Kasahara, K. Manabe, R. Noyori, and H. Takaya, J. Org. Chem., 53, 708 (1988).

(247) BINAP-Ruthenium(II) Dicarboxylate Complexes: New, Highly Efficient Catalysts for Asymmetric Hydrogenations. T. Ohta, H. Takaya, and R. Noyori, Inorg. Chem., 27, 566 (1988).

(248) Three-Component Coupling Synthesis of Prostaglandins: The Aldol Route. M. Suzuki, T. Kawagishi, A. Yanagisawa, T. Suzuki, N. Okamura, and R. Noyori, Bull. Chem. Soc. Jpn., 61, 1299 (1988).

(249) Application of Allyloxycarbonyl Group as a Protecting Group to Oligodeoxyribonucleotide Synthesis. Y. Mitsuhira, S. Tahara, K. Goto, Y. Hayakawa, and R. Noyori, Nucleic Acids Symp. Ser., (19), 25 (1988).

(250) A Practical Asymmetric Synthesis of Carnitine. M. Kitamura, T. Ohkuma, H. Takaya, and R. Noyori, Tetrahedron Lett., 29, 1555 (1988).

(251) Palladium(0)-Catalyzed Isomerization of $\alpha, \beta$-Epoxy Ketones to $\beta$-Diketones. $M$. Suzuki, A. Watanabe, and R. Noyori, Recl. Trav. Chim. Pays-Bas, 107, 230 (1988).

(252) Homogeneous Asymmetric Hydrogenation. R. Noyori, Chimia, 42, 215 (1988).

(253) The Three-Component Coupling Synthesis of Prostaglandins. M. Suzuki, A. Yanagisawa, and R. Noyori, J. Am. Chem. Soc., 110, 4718 (1988).

(254) Trimethylsilyl Triflate Catalyzed Aldol-Type Reaction of Enol Silyl Ethers and Acetals or Related Compounds. S. Murata, M. Suzuki, and R. Noyori, Tetrahedron, 44, 4259 (1988). 
(255) Synthesis of Statine and its Analogues by Homogeneous Asymmetric Hydrogenation. T. Nishi, M. Kitamura, T. Ohkuma, and R. Noyori, Tetrahedron Lett., 29, 6327 (1988).

(256) Allylic Protecting Groups in Solid-Phase DNA Synthesis. Y. Hayakawa, S. Wakabayashi, and R. Noyori, Nucleic Acids Symp. Ser., (20), 75 (1988).

(257) Organometallics in Prostaglandin Synthesis. R. Noyori, A. Yanagisawa, H. Koyano, M. Kitamura, M. Nishizawa, and M. Suzuki, Philos. Trans. R. Soc. London A, 326, 579 (1988).

(258) (R)-(+)- and (S)-(-)-2,2'-Bis(diphenylphosphino)-1,1'-binaphthyl (BINAP). H. Takaya, S. Akutagawa, and R. Noyori, Org. Synth., 67, 20 (1988).

(259) Enantioselective Alkylation of Carbonyl Compounds. From Stoichiometric to Catalytic Asymmetric Induction. R. Noyori, S. Suga, K. Kawai, S. Okada, and M. Kitamura, Pure Appl. Chem., 60, 1597 (1988).

(260) An Organozinc Aid in Alkylation and Acylation of Lithium Enolates. Y. Morita, M. Suzuki, and R. Noyori, J. Org. Chem., 54, 1785 (1989).

(261) Enantioselective Addition of Dialkylzincs to Aldehydes Promoted by Chiral Amino Alcohols. Mechanism and Nonlinear Effect. M. Kitamura, S. Okada, S. Suga, and R. Noyori, J. Am. Chem. Soc., 111, 4028 (1989).

(262) Natural and Unnatural Prostaglandins via the Three-Component Coupling Synthesis. R. Noyori, A. Yanagisawa, H. Koyano, and M. Suzuki, In "Advances in Prostaglandin, Thromboxane, and Leukotriene Research", Vol. 19, B. Samuelsson, P. Y.-K. Wong, and F. F. Sun, Eds., Raven Press, New York, 1989, p 631.

(263) Chemical Multiplication of Chirality: Science and Applications. R. Noyori, Chem. Soc. Rev., 18, 187 (1989).

(264) General, Regiocontrolled Synthesis of Unsymmetrically Linked Dinucleoside Adenosine 2',3'-Bis(phosphate)s. Y. Hayakawa, M. Hirose, and R. Noyori, Nucleic Acids Symp. Ser., (21), 103 (1989).

(265) Prostaglandins Made Simple. R. Noyori, Chem. Brit., 25, 883 (1989).

(266) Synthesis of Functionalized Prostaglandins via the Organozinc-Aided Three-Component Method. $\quad$ M. Suzuki, H. Koyano, Y. Morita, and R. Noyori, Synlett, 22 (1989).

(267) Synthesis of New Cationic BINAP-Ruthenium(II) Complexes and their Use in Asymmetric Hydrogenation [BINAP = 2,2'-bis(diphenylphosphino)-1,1'-binaphthyl]. $\mathrm{K}$. Mashima, K. Kusano, T. Ohta, R. Noyori, and H. Takaya, J. Chem. Soc., Chem. Commun., 1208 (1989).

(268) Ruthenium(II)-Catalyzed Reactions of 1,4-Epiperoxides. M. Suzuki, H. Ohtake, Y. Kameya, N. Hamanaka, and R. Noyori, J. Org. Chem., 54, 5292 (1989).

(269) Stereoselective Hydrogenation via Dynamic Kinetic Resolution. R. Noyori, T. Ikeda, T. Ohkuma, M. Widhalm, M. Kitamura, H. Takaya, S. Akutagawa, N. Sayo, T. Saito, T. Taketomi, and H. Kumobayashi, J. Am. Chem. Soc., 111, 9134 (1989).

(270) Palladium(0) Catalyzed Reactions of 1,4-Epiperoxides. M. Suzuki, Y. Oda, N. Hamanaka, and R. Noyori, Heterocyles, 30, 517 (1990).

(271) Selective Propargylation of Carbonyl Compounds with Allenylstannane/Alkyllithium Mixed Reagents. M. Suzuki, Y. Morita, and R. Noyori, J. Org. Chem., 55, 441 (1990).

(272) Stereoselective Synthesis of a Precursor of $1 \beta$-Methylcarbapenems. M. Kitamura, K. Nagai, Yi Hsiao, and R. Noyori, Tetrahedron Lett. 31, 549 (1990).

(273) Dynamic Kinetic Resolution in BINAP-Ruthenium(II) Catalyzed Hydrogenation of 2Substituted 3-Oxo Carboxylic Esters. M. Kitamura, T. Ohkuma, M. Tokunaga, and R. Noyori, Tetrahedron: Asymmetry, 1, 1 (1990).

(274) The Allylic Protection Method in Solid-Phase Oligonucleotide Synthesis. An Efficient Preparation of Solid-Anchored DNA Oligomers. Y. Hayakawa, S. Wakabayashi, H. Kato, and R. Noyori, J. Am. Chem. Soc., 112, 1691 (1990). 
(275) Enantioselective Addition of Diorganozincs to Aldehydes Catalyzed by $\beta$-Amino Alcohols. $\quad$ R. Noyori, S. Suga, K. Kawai, S. Okada, M. Kitamura, N. Oguni, M. Hayashi, T. Kaneko, and Y. Matsuda, J. Organomet. Chem., 382, 19 (1990).

(276) Organometallic Methodologies for Nucleic Acid Synthesis. R. Noyori, M. Uchiyama, H. Kato, S. Wakabayashi, and Y. Hayakawa, Pure Appl. Chem., 62, 613 (1990).

(277) New Chiral Rh(I) and Ru(II) Complexes: Highly Efficient Catalysts for Homogeneous Asymmetric Hydrogenation. H. Takaya, T. Ohta, K. Mashima, M. Kitamura, and R. Noyori, In "Future Opportunities in Catalytic and Separation Technology: Studies in Surface Science and Catalysis", Vol. 54, M. Misono, Y. Moro-oka, and S. Kimura, Eds., Elsevier, Amsterdam, 1990, p 322.

(278) Mechanism of the Asymmetric Isomerization of Allylamines to Enamines Catalyzed by 2,2'-Bis(diphenylphosphino)-1,1'-binaphthyl-Rhodium Complexes. S. Inoue, H. Takaya, K. Tani, S. Otsuka, T. Sato, and R. Noyori, J. Am. Chem. Soc., 112, 4897 (1990).

(279) An Organometallic Way to Prostaglandins: The Three-Component Coupling Synthesis. R. Noyori and M. Suzuki, Chemtracts-Org. Chem., 3, 173 (1990).

(280) Chiral Metal Complexes as Discriminating Molecular Catalysts. R. Noyori, Science, 248, 1194 (1990).

(281) Three-Component Coupling Synthesis of Prostaglandins. A Simplified, General Procedure. M. Suzuki, Y. Morita, H. Koyano, M. Koga, and R. Noyori, Tetrahedron, 46, 4809 (1990).

(282) Antiviral Effects of 2',5'-Oligoadenylates (2-5As) and Related Compounds. A. Tominaga, S. Saito, S. Kohno, K. Sakurai, Y. Hayakawa, and R. Noyori, Microbiol. Immunol., 34, 737 (1990).

(283) Enantioselective Synthesis of 4-Substituted $\gamma$-Lactones. T. Ohkuma, M. Kitamura, and R. Noyori, Tetrahedron Lett., 31, 5509 (1990).

(284) BINAP: An Efficient Chiral Element for Asymmetric Catalysis. R. Noyori and H. Takaya, Acc. Chem. Res., 23, 345 (1990).

(285) New Chiral Ruthenium Complexes for Asymmetric Catalytic Hydrogenations. H. Takaya, T. Ohta, K. Mashima, and R. Noyori, Pure Appl. Chem., 62, 1135 (1990).

(286) Syntheses of Isocarbacyclin by Highly Regioselective Alkylation of Allylic Alcohols. K. Bannai, T. Tanaka, N. Okamura, A. Hazato, S. Sugiura, K. Manabe, K. Tomimori, Y. Kato, S. Kurozumi, and R. Noyori, Tetrahedron, 46, 6689 (1990).

(287) Synthesis, Molecular Structures, and Solution-Phase Behavior of New Anionic Pentacoordinate Triorganotin(IV) Compounds: Tris(dimethylamino)sulfonium Dichlorotriorganostannates, Bis(2,6-dimethylphenoxy)triorganostannates, and Chloro(2,6-dimethyl-phenoxy)triorganostannates. M. Suzuki, I.-H. Son, R. Noyori, and H. Masuda, Organometallics, 9, 3043 (1990).

(288) Stereochemistry and Mechanism of the Asymmetric Hydrogenation of Unsaturated Carboxylic Acids Catalyzed by BINAP-Ruthenium(II) Dicarboxylate Complexes. T. Ohta, H. Takaya, and R. Noyori, Tetrahedron Lett., 31, 7189 (1990).

(289) Nonclassical Chemistry from the Oldest Organometallic Compounds: Multiplication and Amplification of Chirality. R. Noyori, S. Suga, S. Okada, K. Kawai, and M. Kitamura, In "Organic Synthesis via Organometallics", K. H. Dötz and R. W. Hoffmann, Eds., Vieweg, Braunschweig, 1991, p 311.

(290) Enantioselektive Addition von Organometallreagentien an Carbonylverbindungen: Übertragung, Vervielfältigung und Verstärkung der Chiralität. R. Noyori und M. Kitamura, Angew. Chem., 103, 34 (1991); Enantioselective Addition of Organometallic Reagents to Carbonyl Compounds: Chirality Transfer, Multiplication, and Amplification. R. Noyori and M. Kitamura, Angew. Chem., Int. Ed. Engl., 30, 49 (1991). 
(291) Convenient Preparation of BINAP-Ruthenium(II) Complexes Catalyzing Asymmetric Hydrogenation of Functionalized Ketones. M. Kitamura, M. Tokunaga, T. Ohkuma, and R. Noyori, Tetrahedron Lett., 32, 4163 (1991).

(292) Enantioselective Synthesis of $\beta$-Amino Acids Based on BINAP-Ruthenium(II) Catalyzed Hydrogenation. $\quad$ W. D. Lubell, M. Kitamura, and R. Noyori, Tetrahedron: Asymmetry, 2, 543 (1991).

(293) Direct Synthesis of Solid-Anchored DNA Oligomers. Y. Hayakawa, H. Harada, M. Hirose, R. Noyori, S. Wakabayashi, K. Miyazaki, Y. Kawase, and I. Kato, Nucleic Acids Symp. Ser., (25), 63 (1991).

(294) Practical Synthesis of 2'-5'-Linked Oligoadenylates (2-5A Oligomers). R. Noyori, M. Uchiyama, T. Nobori, M. Hirose, and Y. Hayakawa, Aust. J. Chem., 45, 205 (1992).

(295) An Azido-Functionalized Isocarbacyclin Analogue Acting as an Efficient Photoaffinity Probe for a Prostacyclin Receptor. M. Suzuki, H. Koyano, R. Noyori, H. Hashimoto, M. Negishi, A. Ichikawa, and S. Ito, Tetrahedron, 48, 2635 (1992).

(296) Asymmetric Catalysis by Chiral Metal Complexes. R. Noyori, CHEMTECH, 22, 360 (1992).

(297) Practical Synthesis of BINAP-Ruthenium(II) Dicarboxylate Complexes. M. Kitamura, M. Tokunaga, and R. Noyori, J. Org. Chem., 57, 4053 (1992).

(298) Asymmetric Hydrogenation. R. Noyori, In "Organic Synthesis in Japan: Past, Present, and Future", R. Noyori, Editor-in-Chief, Tokyo Kagaku Dozin, Tokyo, 1992, p 301.

(299) Partial Methyl Phosphotriester-Modification of Oligodeoxyribonucleotides. Y. Hayakawa, M. Hayakawa, M. Hirose, and R. Noyori, Nucleic Acids Symp. Ser., (27), 103 (1992).

(300) Ab Initio Molecular Orbital Study on Rhodium(I)-Catalyzed Isomerization of Allylic Amines to Enamines. M. Yamakawa and R. Noyori, Organometallics, 11, 3167 (1992).

(301) Asymmetric Hydrogenation of 3-Oxo Carboxylates Using BINAP-Ruthenium Complexes: (R)-(-)-Methyl 3-Hydroxybutanoate. M. Kitamura, M. Tokunaga, T. Ohkuma, and R. Noyori, Org. Synth., 71, 1 (1992).

(302) Identification of the Prostacyclin Receptor by Use of [15-3 $\left.\mathrm{H}_{1}\right] 19-(3-$-Azidophenyl)-20norisocarbacyclin, an Irreversible Specific Photoaffinity Probe. S. Ito, H. Hashimoto, M. Negishi, M. Suzuki, H. Koyano, R. Noyori, and A. Ichikawa, J. Biol. Chem., 267, 20326 (1992).

(303) Organic Synthesis of Prostaglandins: Advancing Biology. R. Noyori and M. Suzuki, Science, 259, 44 (1993).

(304) Asymmetric Terpene Synthesis. R. Noyori, In "Recent Developments in Flavor and Fragrance Chemistry", R. Hopp and K. Mori, Eds., VCH, Weinheim, 1993, p 3.

(305) Quantitative Expression of Dynamic Kinetic Resolution of Chirally Labile Enantiomers: Stereoselective Hydrogenation of 2-Substituted 3-Oxo Carboxylic Esters Catalyzed by BINAP-Ruthenium(II) Complexes. M. Kitamura, M. Tokunaga, and R. Noyori, J. Am. Chem. Soc., 115, 144 (1993).

(306) O-Selective Phosphorylation of Nucleosides without N-Protection. M. Uchiyama, Y. Aso, R. Noyori, and Y. Hayakawa, J. Org. Chem., 58, 373 (1993).

(307) Mathematical Treatment of Kinetic Resolution of Chirally Labile Substrates. M. Kitamura, M. Tokunaga, and R. Noyori, Tetrahedron, 49, 1853 (1993).

(308) Practical Synthesis of Chiral Secondary Alcohols for the Preparation of Ferroelectric Liquid Crystals. R. Noyori and M. Kitamura, In "New Functionality Materials, Volume C, Synthetic Process and Control of Functionality Materials", T. Tsuruta, M. Doyama, and M. Seno, Eds., Elsevier, Amsterdam, 1993, p 389.

(309) O-Allyl Protection of Guanine and Thymine Residues in Oligodeoxyribonucleosides. Y. Hayakawa, M. Hirose, and R. Noyori, J. Org. Chem., 58, 5551 (1993). 
(310) Asymmetric Hydrogenation of Allylic Alcohols Using BINAP-Ruthenium Complexes: (S)-(-)-Citronellol. H. Takaya, T. Ohta, S.-i. Inoue, M. Tokunaga, M. Kitamura, and R. Noyori, Org. Synth., 72, 74 (1993).

(311) Synthesis of Phenylphosphonodiester-Modified Oligodeoxyribonucleotides via the Allyl Protection. M. Hirose, R. Noyori, and Y. Hayakawa, Nucleic Acids Symp. Ser., 29, 7 (1993).

(312) A Practical Method for Activation of Commercial Lithium Hydride: Reductive Silylation of Carbonyl Compounds with Lithium Hydride and Chlorotrimethylsilane. T. Ohkuma, S. Hashiguchi, and R. Noyori, J. Org. Chem., 59, 217 (1994).

(313) General Asymmetric Synthesis of Isoquinoline Alkaloids. Enantioselective Hydrogenation of Enamides Catalyzed by BINAP-Ruthenium(II) Complexes. M. Kitamura, Yi Hsiao, M. Ohta, M. Tsukamoto, T. Ohta, H. Takaya, and R. Noyori, J. Org. Chem., 59, 297 (1994).

(314) Homogeneous Catalytic Hydrogenation of Supercritical Carbon Dioxide. P. G. Jessop, T. Ikariya, and R. Noyori, Nature, 368, 232 (1994).

(315) Organometallic Ways for the Multiplication of Chirality. R. Noyori, Tetrahedron, 50, 4259 (1994).

(316) Synthesis of 3-Substituted But-3-enoic Acids via Palladium Catalysed Cross-Coupling Reaction of 3-Iodobut-3-enoic Acid with Organometallic Reagents. A. Duchêne, M. Abarbri, J-L. Parrain, M. Kitamura, and R. Noyori, Synlett, 524 (1994).

(317) Binaphthyls as Chiral Elements for Asymmetric Synthesis. R. Noyori, In "(IUPAC) Stereocontrolled Organic Synthesis", B. M. Trost, Ed., Blackwell Scientific Publications, Oxford, 1994, p 1.

(318) Unnatural Prostaglandins of Biochemical and Physiological Significance. R. Noyori, H. Koyano, M. Mori, R. Hirata, Y. Shiga, T. Kokura, and M. Suzuki, Pure Appl. Chem., 66, 1999 (1994).

(319) Catalytic Production of Dimethylformamide from Supercritical Carbon Dioxide. P. G. Jessop, Yi Hsiao, T. Ikariya, and R. Noyori, J. Am. Chem. Soc., 116, 8851 (1994).

(320) Enantiomer Recognition of Asymmetric Catalysts. Thermodynamic Properties of Homochiral and Heterochiral Dimers of the Methylzinc Alkoxide Formed from Dimethylzinc and Enantiomeric 3-exo-(Dimethylamino)isoborneol. M. Kitamura, S. Suga, M. Niwa, R. Noyori, Z.-X. Xhai, and H. Suga, J. Phys. Chem., 98, 12776 (1994).

(321) Living Polymerization of Phenylacetylenes Initiated by $\mathrm{Rh}\left(\mathrm{C} \equiv \mathrm{CC}_{6} \mathrm{H}_{5}\right)(2,5$ -

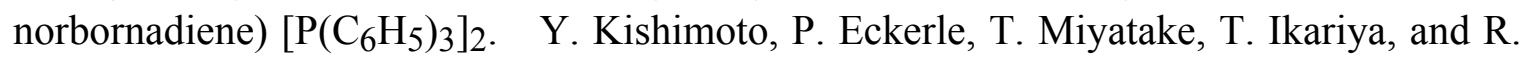
Noyori, J. Am. Chem. Soc., 116, 12131 (1994).

(322) Stereoselective Organic Synthesis via Dynamic Kinetic Resolution. R. Noyori, M. Tokunaga, and M. Kitamura, Bull. Chem. Soc. Jpn., 68, 36 (1995).

(323) Practical Enantioselective Hydrogenation of Aromatic Ketones. T. Ohkuma, H. Ooka, H. Hashiguchi, T. Ikariya, and R. Noyori, J. Am. Chem. Soc., 117, 2675 (1995).

(324) Selectivity for Hydrogenation or Hydroformylation of Olefins by Hydridopentacarbonylmanganese(I) in Supercritical Carbon Dioxide. P. G. Jessop, T. Ikariya, and R. Noyori, Organometallics, 14, 1510 (1995).

(325) General Synthesis and Binding Affinity of Position-Selective Phosphonodiester- and Phosphotriester-Incorporated Oligodeoxyribonucleotides. Y. Hayakawa, M. Hirose, M. Hayakawa, and R. Noyori, J. Org. Chem., 60, 925 (1995).

(326) Asymmetric Hydrogenation of $\beta$-Keto Phosphonates: A Practical Way to Fosfomycin. M. Kitamura, M. Tokunaga, and R. Noyori, J. Am. Chem. Soc., 117, 2931 (1995).

(327) Methyl Formate Synthesis by Hydrogenation of Supercritical Carbon Dioxide in the Presence of Methanol. P. G. Jessop, Yi Hsiao, T. Ikariya, and R. Noyori, J. Chem. Soc., Chem. Commun., 707 (1995). 
(328) Homogeneous Hydrogenation of Carbon Dioxide. P. G. Jessop, T. Ikariya, and R. Noyori, Chem. Rev., 95, 259 (1995).

(329) Self and Nonself Recognition of Asymmetric Catalysts. Nonlinear Effects in the Amino Alcohol-Promoted Enantioselective Addition of Dialkylzincs to Aldehydes. M. Kitamura, S. Suga, M. Niwa, and R. Noyori, J. Am. Chem. Soc., 117, 4832 (1995).

(330) An Ab Initio Molecular Orbital Study on the Amino Alcohol-Promoted Reaction of Dialkylzincs and Aldehydes. M. Yamakawa and R. Noyori, J. Am. Chem. Soc., 117, 6327 (1995).

(331) Asymmetric Transfer Hydrogenation of Aromatic Ketones Catalyzed by Chiral Ruthenium(II) Complexes. S. Hashiguchi, A. Fujii, J. Takehara, T. Ikariya, and R. Noyori, J. Am. Chem. Soc., 117, 7562 (1995).

(332) Asymmetric Synthesis of $\alpha$-Amino $\beta$-Hydroxy Phosphonic Acids via BINAP-Ruthenium Catalyzed Hydrogenation. M. Kitamura, M. Tokunaga, T. Pham, W. D. Lubell, and R. Noyori, Tetrahedron Lett., 32, 5769 (1995).

(333) Homogeneous Catalysis in Supercritical Fluids. P. G. Jessop, T. Ikariya, and R. Noyori, Science, 269, 1065 (1995).

(334) Regiodefined Synthesis and Conformational Properties of Adenyldiyl Trimers with Unsymmetrical 2'-5' and 3'-5' Internucleotide Linkages. Y. Hayakawa, M. Hirose, and R. Noyori, Tetrahedron, 51, 9899 (1995).

(335) Polymerization of Monosubstituted Acetylenes with a Zwitterionic Rhodium(I) Complex, $\mathrm{Rh}^{+}(2,5$-norbornadiene $)\left[\left(\eta^{6}-\mathrm{C}_{6} \mathrm{H}_{5}\right) \mathrm{B}^{-}\left(\mathrm{C}_{6} \mathrm{H}_{5}\right)_{3}\right] . \quad$ Y. Kishimoto, M. Itou, T. Miyatake, $\mathrm{T}$. Ikariya, and R. Noyori, Macromolecules, 28, 6662 (1995).

(336) Preferential Hydrogenation of Aldehydes and Ketones. T. Ohkuma, H. Ooka, T. Ikariya, and R. Noyori, J. Am. Chem. Soc., 117, 10417 (1995).

(337) Homogeneous Catalysis in Supercritical Fluids: Hydrogenation of Supercritical Carbon Dioxide to Formic Acid, Alkyl Formates, and Formamides. P. G. Jessop, Yi Hsiao, T. Ikariya, and R. Noyori, J. Am. Chem. Soc., 118, 344 (1996).

(338) (15R)-16-m-Tolyl-17,18,19,20-tetranorisocarbacyclin: ein stabiler, hochselektiver Ligand mit hoher Bindungsaffinität für einen Prostacyclin-Rezeptor im zentralen Nervensystem. M. Suzuki, K. Kato, R. Noyori, Y. Watanabe, H. Takechi, K. Matsumura, B. Långström, und Y. Watanabe, Angew. Chem., 108, 366 (1996); (15R)-16-m-Tolyl-17,18,19,20tetranorisocarbacyclin: A Stable Ligand with High Binding Affinity and Selectivity for a Prostacyclin Receptor in the Central Nervous System. M. Suzuki, K. Kato, R. Noyori, Y. Watanabe, H. Takechi, K. Matsumura, B. Långström, and Y. Watanabe, Angew. Chem., Int. Ed. Engl., 35, 334 (1996).

(339) A Ruthenium(II) Complex with a $C_{2}$-Symmetric Diphosphine/Diamine Tetradentate Ligand for Asymmetric Transfer Hydrogenation of Aromatic Ketones. J.-X. Gao, T. Ikariya, and R. Noyori, Organometallics, 15, 1087 (1996).

(340) Amino Alcohol Effects on the Ruthenium(II)-Catalysed Asymmetric Transfer Hydrogenation of Ketones in Propan-2-ol. J. Takehara, S. Hashiguchi, A. Fujii, S. Inoue, T. Ikariya, and R. Noyori, J. Chem. Soc., Chem. Commun., 233 (1996).

(341) A Novel Subtype of the Prostacyclin Receptor Expressed in the Central Nervous System. H. Takechi, K. Matsumura, Y. Watanabe, K. Kato, R. Noyori, M. Suzuki, and Y. Watanabe, J. Biol. Chem., 271, 5901 (1996).

(342) Ruthenium(II)-Catalyzed Asymmetric Transfer Hydrogenation of Ketones Using a Formic Acid-Triethylamine Mixture. A. Fujii, S. Hashiguchi, N. Uematsu, T. Ikariya, and R. Noyori, J. Am. Chem. Soc., 118, 2521 (1996).

(343) Asymmetric Hydrogenation of $\alpha, \beta$-Unsaturated Carboxylic Acids in Supercritical Carbon Dioxide. J. Xiao, S. C. A. Nefkens, P. G. Jessop, T. Ikariya, and R. Noyori, Tetrahedron Lett., 37, 2813 (1996). 
(344) Conformational Study on 2-Acyl-1-alkylidene-1,2,3,4-tetrahydroisoquinolines. M. Kitamura, M. Tsukamoto, H. Takaya, and R. Noyori, Bull. Chem. Soc. Jpn., 69, 1695 (1996).

(345) Asymmetric Transfer Hydrogenation of Imines. N. Uematsu, A. Fujii, S. Hashiguchi, T. Ikariya, and R. Noyori, J. Am. Chem. Soc., 118, 4916 (1996).

(346) Asymmetric Hydrogenation. R. Noyori, Acta Chem. Scand., 50, 380 (1996).

(347) An Efficient Rhodium(I) Initiator for Stereospecific Living Polymerization of Phenylacetylenes. Y. Kishimoto, T. Miyatake, T. Ikariya, and R. Noyori, Macromolecules 29, 5054 (1996).

(348) Conjugate Addition of Diorganozincs to $\alpha, \beta$-Unsaturated Ketones Catalyzed by a Copper(I)-Sulfonamide Combined System. M. Kitamura, T. Miki, K. Nakano, and R. Noyori, Tetrahedron Lett., 37, 5141 (1996).

(349) Stereoselective Hydrogenation of Simple Ketones Catalyzed by Ruthenium(II) Complexes. T. Ohkuma, H. Ooka, M. Yamakawa, T. Ikariya, and R. Noyori, J. Org. Chem., 61, 4872 (1996).

(350) Homochiral and Heterochiral Dimers of the Methylzinc Alkoxide Formed from Dimethylzinc and Enantiomeric 3-exo-(Dimethylamino)isoborneol-Origin of the Distinct Differences in Solution-Phase Behavior and Crystal Structures. M. Kitamura, M. Yamakawa, H. Oka, S. Suga, and R. Noyori, Chem. Eur. J., 2, 1173 (1996).

(351) Benzimidazolium Triflate as an Efficient Promoter for Nucleotide Synthesis via the Phosphoramidite Method. Y. Hayakawa, M. Kataoka, and R. Noyori, J. Org. Chem., 61, 7996 (1996).

(352) A Practical Method for Epoxidation of Terminal Olefins with 30\% Hydrogen Peroxide under Halide-Free Conditions. K. Sato, M. Aoki, M. Ogawa, T. Hashimoto, and R. Noyori, J. Org. Chem., 61, 8310 (1996).

(353) Synthesis of $\alpha$-Amino Phosphonic Acids by Asymmetric Hydrogenation. M. Kitamura, M. Yoshimura, M. Tsukamoto, and R. Noyori, Enantiomer, 1, 281 (1996).

(354) Induction of $M R P / G S-X$ Pump and Cellular Resistance to Anticancer Prostglandins. K. Akimaru, M. T. Kuo, K. Furuta, M. Suzuki, R. Noyori, and T. Ishikawa, Cytotechnology, 19, 221 (1996).

(355) Katalysatorvorstufe, Katalysator und Zwischenstufe des Ru $\mathrm{R}^{\mathrm{II}}$-katalysierten, asymmetrischen Wasserstofftransfers zwischen Alkoholen und Ketonen. K.-J. Haack, S. Hashiguchi, A. Fujii, T. Ikariya und R. Noyori, Angew. Chem., 109, 297 (1997); The Catalyst Precursor, Catalyst, and Intermediate in the $\mathrm{Ru}^{\mathrm{II}}$-Promoted Asymmetric Hydrogen Transfer between Alcohols and Ketones. K.-J. Haack, S. Hashiguchi, A. Fujii, T. Ikariya, and R. Noyori, Angew. Chem., Int. Ed. Engl., 36, 285 (1997).

(356) Kinetische Racematspaltung sekundärer Alkohole durch Ruthenium(II)-katalysierte Transferhydrierung. S. Hashiguchi, A. Fujii, K.-J. Haack, K. Matsumura, T. Ikariya und R. Noyori, Angew. Chem., 109, 300 (1997); Kinetic Resolution of Racemic Secondary Alcohols by RuII-Catalyzed Hydrogen Transfer. S. Hashiguchi, A. Fujii, K.-J. Haack, K. Matsumura, T. Ikariya, and R. Noyori, Angew. Chem., Int. Ed. Engl., 36, 288 (1997).

(357) Asymmetric Transfer Hydrogenation Catalyzed by Chiral Ruthenium Complexes. R. Noyori and S. Hashiguchi, Acc. Chem. Res., 30, 97 (1997).

(358) Chemical Implications for Antitumor and Antiviral Prostaglandins: Reaction of $\Delta^{7}$ Prostaglandin $A_{1}$ and Prostaglandin $A_{1}$ Methyl Esters with Thiols. M. Suzuki, M. Mori, T. Niwa, R. Hirata, K. Furuta, T. Ishikawa, and R. Noyori, J. Am. Chem. Soc., 119, 2376 (1997).

(359) A Halide-Free Method for Olefin Epoxidation with 30\% Hydrogen Peroxide. K. Sato, M. Aoki, M. Ogawa, T. Hashimoto, D. Panyella, and R. Noyori, Bull. Chem. Soc. Jpn., 70, 905 (1997). 
(360) Asymmetric Hydrogenation of Cyclic $\alpha, \beta$-Unsaturated Ketones to Chiral Allylic Alcohols. T. Ohkuma, H. Ikehira, T. Ikariya, and R. Noyori, Synlett, 5, 467 (1997).

(361) Asymmetric Transfer Hydrogenation Catalyzed by Diamine-Iridium(I) Complexes. S. Inoue, K. Nomura, S. Hashiguchi, R. Noyori, and Y. Izawa, Chem. Lett., 957 (1997).

(362) Asymmetric Transfer Hydrogenation of $\alpha, \beta$-Acetylenic Ketones. K. Matsumura, S. Hashiguchi, T. Ikariya, and R. Noyori, J. Am. Chem. Soc., 119, 8738 (1997).

(363) Rapid Coupling of Methyl Iodide with Aryltributylstannanes Mediated by Palladium(0) Complexes: A General Protocol for the Synthesis of ${ }^{11} \mathrm{CH}_{3}$-Labeled PET Tracers. M. Suzuki, H. Doi, M. Björkman, Y. Andersson, B. Långström, Y. Watanabe, and R. Noyori, Chem. Eur. J., 12, 2039 (1997).

(364) Organic Solvent- and Halide-Free Oxidation of Alcohols with Aqueous Hydrogen Peroxide. K. Sato, M. Aoki, J. Takagi, and R. Noyori, J. Am. Chem. Soc., 119, 12386 (1997).

(365) $\Delta^{7}$-Prostaglandin $\mathrm{C}_{1}$ : A Primary Metabolite of Antitumor $\Delta^{7}$-Prostaglandin $\mathrm{A}_{1}$ in the Sera. M. Suzuki, T. Kiho, K. Furuta, S. Fukushima, Y. Takeuchi, and R. Noyori, Tetrahedron, 53, 17009 (1997).

(366) Asymmetric Activation of Racemic Ruthenium(II) Complexes for Enantioselective Hydrogenation. T. Ohkuma, H. Doucet, T. Pham, K. Mikami, T. Korenaga, M. Terada, and R. Noyori, J. Am. Chem. Soc., 120, 1086 (1998).

(367) Solid-State NMR Study of Poly(phenylacetylene) Synthesized with a Rhodium Complex Initiator. K. Hirao, Y. Ishii, T. Terao, Y. Kishimoto, T. Miyatake, T. Ikariya, and R. Noyori, Macromolecules, 31, 3405 (1998).

(368) Rational Design of Antitumor Prostaglandins with High Biological Stability. M. Suzuki, T. Kiho, K. Tomokiyo, K. Furuta, S. Fukusima, Y. Takeuchi, M. Nakanishi, and R. Noyori, J. Med. Chem., 41, 3084 (1998).

(369) trans-[RuCl 2 (phosphan) $)_{2}(1,2-$ diamin) $]-\quad$ und chirale trans-[ $\mathrm{RuCl}_{2}$ (diphosphan)(1,2diamin)]-Komplexe: lagerstabile Katalysatorvorstufen für die schnelle, produktive und stereoselektive Hydrierung von Ketonen. H. Doucet, T. Ohkuma, K. Murata, T. Yokozawa, M. Kozawa, E. Katayama, A. F. England, T. Ikariya, und R. Noyori, Angew. Chem., 110, 1792 (1998); trans-[RuCl 2 (phosphane) 2 (1,2-diamine)] and Chiral trans$\left[\mathrm{RuCl}_{2}\right.$ (diphosphane)(1,2-diamine): Shelf-Stable Precatalysts for the Rapid, Productive, and Stereoselective Hydrogenation of Ketones. H. Doucet, T. Ohkuma, K. Murata, T. Yokozawa, M. Kozawa, E. Katayama, A. F. England, T. Ikariya, and R. Noyori, Angew. Chem., Int. Ed. Engl., 37, 1703 (1998).

(370) A "Green" Route to Adipic Acid: Direct Oxidation of Cyclohexenes with 30\% Hydrogen Peroxide. K. Sato, M. Aoki, and R. Noyori, Science, 281, 1646 (1998).

(371) Synthesis of ${ }^{11} \mathrm{C} /{ }^{13} \mathrm{C}$-Labelled Prostacyclins. M. Björkman, Y. Andersson, H. Doi, K. Kato, M. Suzuki, R. Noyori, Y. Watanabe, and B. Langström, Acta Chem. Scand., 52, 635 (1998).

(372) Hydrogen Peroxide Oxidation of Benzylic Alcohols to Benzaldehydes and Benzoic Acids Under Halide-Free Conditions. K. Sato, J. Takagi, M. Aoki, and R. Noyori, Tetrahedron Lett., 39, 7549 (1998).

(373) Quantitative Analysis of the Chiral Amplification in the Amino Alcohol-Promoted Asymmetric Alkylation of Aldehydes with Dialkylzincs. M. Kitamura, S. Suga, H. Oka, and R. Noyori, J. Am. Chem. Soc., 120, 9800 (1998).

(374) Asymmetric Hydrogenation of Alkenyl, Cyclopropyl, and Aryl Ketones. $\mathrm{RuCl}_{2}$ (xylbinap)(1,2-diamine) as a Precatalyst Exhibiting a Wide Scope. T. Ohkuma, M. Koizumi, H. Doucet, T. Pham, M. Kozawa, K. Murata, E. Katayama, T. Yokozawa, T. Ikariya, and R. Noyori, J. Am. Chem. Soc., 120, 13529 (1998). 
(375) Anti-cancer-prostaglandin-Induced Cell-cycle Arrest and Modulation by an Inhibitor of the ATP-Dependent Glutathione S-Conjugate Export Pump (GS-X Pump). T. Ishikawa, K. Akimaru, M. Nakanishi, K. Tomokiyo, K. Furuta, M. Suzuki, and R. Noyori, Biochem. J., 336569 (1998).

(376) Asymmetric Addition of Dimethylzinc to Benzaldehyde Catalyzed by (2S)-3-exo(Dimethylamino)isoborneol. A Theoretical Study on the Origin of Enantioselection. M. Yamakawa and R. Noyori, Organometallics, 18, 128 (1999).

(377) Supercritical Fluids: Introdution. R. Noyori, Chem. Rev., 99, 353 (1999).

(378) Homogenous Catalysis in Supercritical Fluids. P. G. Jessop, T. Ikariya, and R. Noyori, Chem. Rev., 99, 475 (1999).

(379) Asymmetric Addition of Dialkylzincs to Benzaldehyde Derivatives Catalyzed by Chiral $\beta$-Amino Alcohols. Evidence for the Monomeric Alkylzinc Aminoalkoxide as Catalyst. M. Kitamura, H. Oka, and R. Noyori, Tetrahedron, 55, 3605 (1999).

(380) 15-Deoxy-16-( $m$-tolyl)-17,18,19,20-tetranorisocarbacyclin: A Simple TIC Derivative with Potent Anti-apoptotic Activity for Neuronal Cells. M. Suzuki, K. Kato, Y. Watanabe, T. Satoh, K. Matsumura, Y. Watanabe, and R. Noyori, J. Chem. Soc., Chem. Commun., 307 (1999).

(381) New Chiral Rhodium and Iridium Complexes with Chiral Diamine Ligands for Asymmetric Transfer Hydrogenation of Aromatic Ketones. K. Murata, T. Ikaraya, and R. Noyori, J. Org. Chem., 64, 2186 (1999).

(382) Konformative flexible Biphenyl-Phosphan-liganden für Ru-katalysierte enantioselektive Hydrierungen. K. Mikami, T. Korenaga, M. Terada, T. Ohkuma, T. Pham und R. Noyori, Angew. Chem., 111, 517 (1999); Conformationally Flexible Biphenyl-phosphane Ligands for Ru-Catalyzed Enantioselective Hydrogenation. K. Mikami, T. Korenaga, M. Terada, T. Ohkuma, T. Pham, and R. Noyori, Angew. Chem., Int. Ed. Engl., 38, 495 (1999).

(383) A Novel Approach to Oligodeoxyribonucleotides Bearing Phosphoric Acid Esters at the 3'-Terminals via the Phosphoramidite Method with Allyl Protection: an Efficient Synthesis of Base-Labile Nucleotide-Amino Acid and -Peptide Conjugates. A. Sakakura, Y. Hayakawa, H. Harada, M. Hirose, and R. Noyori, Tetrahedron Lett., 40, 4359 (1999).

(384) Organic Reactions in Supercritical Fluids. T. Ikariya and R. Noyori, In "(IUPAC) Transition Metal Catalysed Reactions", S-i Murahashi and S. G. Davies, Eds., Blackwell Scientific Publications, Oxford, 1999, p 1.

(385) Asymmetric Synthesis of $\beta$-Hydroxy Sulfonic Acids by BINAP/Ru-Catalyzed Hydrogenation. M. Kitamura, M. Yoshimura, N. Kanda, and R. Noyori, Tetrahedron, 55, 8769 (1999).

(386) An Efficient Carbonylation of Aryl Halides Catalysed by Palladium Complexes with Phosphite Ligands in Supercritical Carbon Dioxide. Y. Kayaki, Y. Noguchi, S. Iwasa, T. Ikariya, and R. Noyori, J. Chem. Soc., Chem. Commun., 1235 (1999).

(387) A Practical Stereoselective Synthesis of Chiral Hydrobenzoins via Asymmetric Transfer Hydrogenation of Benzils. K. Murata, K. Okano, M. Miyagi, H. Iwane, R. Noyori, and T. Ikariya, Org. Lett., 1, 1119 (1999).

(388) A Practical Method for Alcohol Oxidation with Aqueous Hydrogen Peroxide under Organic Solvent- and Halide-Free Conditions. K. Sato, M. Aoki, J. Takagi, K. Zimmerman, and R. Noyori, Bull. Chem. Soc. Jpn., 72, 2287 (1999).

(389) Well-Controlled Polymerization of Phenylacetylenes with Organorhodium(I) Complexes: Mechanism and Structure of the Polyenes. Y. Kishimoto, P. Eckerle, T. Miyatake, M. Kainosho, A. Ono, T. Ikariya, and R. Noyori, J. Am. Chem. Soc., 121, 12035 (1999).

(390) Rapid, Productive and Stereoselective Hydrogenation of Ketones. R. Noyori and T. Ohkuma, Pure Appl. Chem., 71, 1493 (1999). 
(391) Efficient Synthesis of Optically Active 2-Amino-2'-diphenylphosphino-1,1'-binaphthyl and its Synthesis. K. Sumi, T. Ikariya, and R. Noyori, Can. J. Chem., 78, 697 (2000).

(400) Asymmetric Transfer Hydrogenation of Benzaldehydes. I. Yamada and R. Noyori, Org. Lett., 2, 3425 (2000).

(401) Asymmetric Activation/Deactivation of Racemic $\mathrm{Ru}$ Catalysts for Highly Enantioselective Hydrogenation of Ketonic Substrates. K. Mikami, T. Korenaga, T. Ohkuma, and R. Noyori, Angew. Chem. Int. Ed. Engl., 39, 3707 (2000).

(402) Synthesis of a ${ }^{11} \mathrm{C}$-Labelled Prostaglandin $\mathrm{F}_{2 \alpha}$ Analogue Using an Improved Method for Stille Reaction with [ $\left.{ }^{11} \mathrm{C}\right]-$ Methyl Iodide. M. Björkman, H. Doi, B. Resul, M. Suzuki, R. Noyori, Y. Watanabe, and B. Långström, J. Labelled Cpd. Radiopharm., 43, 1327 (2000).

(403) Asymmetric Hydrogenation of $\alpha$-Ethylstyrenes Catalyzed by Chiral Ruthenium Complexes. G. S. Forman, T. Ohkuma, W. P. Hems, and R. Noyori, Tetrahedron Lett., 41, 9471 (2000).

(404) Asymmetrische Katalyse mit hinsichtlich Struktur und Funktion gezielt entworfenen Molekülen: die chemo- und stereoselektive Hydrierung von Ketonen. R. Noyori und T. Ohkuma, Angew. Chem., 113, 41 (2001); Asymmetric Catalysis by Architectural and Functional Molecular Engineering: Practical Chemo- and Stereoselective Hydrogenation of Ketones. R. Noyori and T. Ohkuma, Angew. Chem., Int. Ed., 40, 40 (2001).

(405) Self and Nonself Recognition of Chiral Catalysts: The Origin of Nonlinear Effects in the Amino-Alcohol Catalyzed Asymmetric Addition of Diorganozincs to Aldehydes. R. Noyori, S. Suga, H. Oka, and M. Kitamura, Chem. Rec., 1, 85 (2001).

(406) Oxidation of Sulfides to Sulfoxides and Sulfones with 30\% Hydrogen Peroxide Under Organic Solvent- and Halogen-Free Conditions. K. Sato, M. Hyodo, M. Aoki, X. Zheng, and R. Noyori, Tetrahedron, 57, 2469 (2001).

(407) Asymmetric Hydrogenation of Ketones with Polymer-Bound BINAP/Diamine Ruthenium Catalysts. T. Ohkuma. H. Takeno, Y. Honda, and R. Noyori, Adv. Synth. Catal., 343, 369 (2001). 
(408) Asymmetric Hydrogenation via Architectural and Functional Molecular Engineering. R. Noyori, M. Koizumi, D. Ishii, and T. Ohkuma, Pure Appl. Chem., 73, 227 (2001).

(409) Catalytic Asymmetric Aldol Reaction of Ketones and Aldehydes using Chiral Calcium Alkoxides. T. Suzuki, N. Yamagiwa, Y. Matsuo, S. Sakamoto, K. Yamaguchi, M. Shibasaki, and R. Noyori, Tetrahedron Lett., 42, 4669 (2001).

(410) Acid/Azole Complexes as Highly Effective Promoters in the Synthesis of DNA and RNA Oligomers via the Phosphoramidite Method. Y. Hayakawa, R. Kawai, A. Hirata, J. Sugimoto, M. Kataoka, A. Sakakura, M. Hirose, and R. Noyori, J. Am. Chem. Soc., 123, 8165 (2001).

(411) Stereochemistry of Aldols: Configuration and Conformation of Aldols Derived from Cycloalkanones and Aldehydes. M. Kitamura, K. Nakano, T. Miki, M. Okada, and R. Noyori, J. Am. Chem. Soc., 123, 8939 (2001).

(412) $\mathrm{CH} / \pi$ Attraction: The Origin of Enantioselectivity in Transfer Hydrogenation of Aromatic Carbonyl Compounds Catalyzed by Chiral $\eta^{6}$-Arene-Ruthenium(II) Complexes. M. Yamakawa, I. Yamada, and R. Noyori, Angew. Chem., Int. Ed., 40, 2818 (2001).

(413) Metal-Ligand Bifunctional Catalysis: A Nonclassical Mechanism for Asymmetric Hydrogen Transfer between Alcohols and Carbonyl Compounds. R. Noyori, M. Yamakawa, and S. Hashiguchi, J. Org. Chem., 66, 7931 (2001).

(414) trans- $\mathrm{RuH}\left(\eta^{1}-\mathrm{BH}_{4}\right)$ (binap)(1,2-diamine): A Catalyst for Asymmetric Hydrogenation of Simple Ketones under Base-Free Conditions. T. Ohkuma, M. Koizumi, K. Muñiz, G. Hilt, C. Kabuto, and R. Noyori, J. Am. Chem. Soc., 124, 6508 (2002).

(415) Mechanism of Asymmetric Hydrogenation of $\alpha$-(Acylamimo)acrylic Esters Catalyzed by BINAP-Ruthenium(II) Diacetate. M. Kitamura, M. Tsukamoto, Y. Bessho, M. Yoshimura, U. Kobs, M. Widhalm, and R. Noyori, J. Am. Chem. Soc., 124, 6649 (2002).

(416) Asymmetrische Katalyse: Kenntnisstand und Perspektiven (Nobel-Vortrag). R. Noyori, Angew. Chem., 114, 2108 (2002); Aymmetric Catalysis: Science and Opportunities (Nobel Lecture). ～R. Noyori, Angew. Chem., Int. Ed., 41, 2008 (2002).

(417) Pressure-dependent Enantioselectivity in the Organozinc Addition to Aldehydes in Supercritical Fluids. P. G. Jessop, R. A. Brown, M. Yamakawa, J. Xiao, T. Ikariya, M. Kitamura, S. C. Tucker, and R. Noyori, J. Supercrit. Fluids, 24, 161 (2002).

(418) Practical Synthesis of Optically Active Styrene Oxides via Reductive Transformation of 2-Chloroacetophenones with Chiral Rhodium Catalysts. T. Hamada, T.Torii, K. Izawa, R. Noyori, and T. Ikariya, Org. Lett., 4, 4373 (2002).

(419) Iterative Synthesis of the ABCDEF-ring System of Yessotoxin and Adriatoxin. Y. Mori, T. Takase, and R. Noyori, Tetrahedron Lett., 44, 2319 (2003).

(420) Green Oxidation with Aqueous Hydrogen Peroxide. R. Noyori, M. Aoki, and K. Sato, Chem. Commun., 1977 (2003).

(421) Mechanism of Asymmetric Hydrogenation of Ketones Catalyzed by BINAP/1,2-DiamineRuthenium(II) Complexes. C. A. Sandoval, T. Ohkuma, K. Muñiz, and R. Noyori, J. Am. Chem. Soc., 125, 13490 (2003).

(422) Sulfonyl-Stabilized Oxiranyllithium-Based Approach to Polycyclic Ethers. Convergent Synthesis of the ABCDEF-Ring System of Yessotoxin and Adriatoxin. Y. Mori, K. Nogami, H. Hayashi, and R. Noyori, J. Org. Chem., 68, 9050 (2003).

(423) Synthesis of trans-Fused Polycyclic Ethers with Angular Methyl Groups Using SulfonylStabilized Oxirany Anions. H. Furuta, T. Takase, H. Hayashi, R. Noyori, and Y. Mori, Tetrahedron, 59, 9767 (2003).

(424) ${ }^{7} \mathrm{Li}$ - and ${ }^{31} \mathrm{P}-\mathrm{NMR}$ Spectra of Cyclopentanone Lithium Enolate in Ethereal Solvents: Identification of the HMPA-Coordinated Aggregate Structures. M. Suzuki, H. Koyama, and R. Noyori, Tetrahedron, 60, 1571 (2004).

(425) Effects of HMPA on the Structure and Reactivity of the Lithium Enolate of Cyclopentanone in THF: The Dimer is Responsible for Alkylation and Proton Exchange 
Reactions. M. Suzuki, H. Koyama, and R. Noyori, Bull. Chem. Soc. Jpn., 77, 259 (2004).

(426) Toward Efficient Asymmetric Hydrogenation: Architectural and Functional Engineering of Chiral Molecular Catalysts. R. Noyori, M. Kitamura, and T. Ohkuma, Proc. Natl. Acad. Sci. USA, 101, 5356 (2004).

(427) BINAP/1,4-Diamine-Ruthenium(II) Complexes for Efficient Asymmetric Hydrogenation of 1-Tetralones and Analogues. T. Ohkuma, T. Hattori, H. Ooka, T. Inoue, and R. Noyori, Org. Lett., 6, 2681 (2004).

(428) Asymmetric Hydrogenation of 2-Arylated Cycloalkanones through Dynamic Kinetic Resolution. T. Ohkuma, J. Li, and R. Noyori, Synlett, 1383 (2004).

(429) A Very Reliable Method for Determination of Absolute Configuration of Chiral Secondary Alcohols by ${ }^{1} \mathrm{H}$ NMR Spectroscopy. Y. Takeuchi, H. Fujisawa, and R. Noyori, Org. Lett., 6, 4607 (2004).

(430) Catalytic Enantioselective Addition of Dialkylzincs to Aldehydes Using (2S)-(-)-3-exo(Dimethylamino)isoborneol [(2S)-DAIB]: (S)-1-Phenyl-1-propanol. M. Kitamura, H. Oka, S. Suga, K. Nakano, and R. Noyori, Org. Synth., Coll. Vol. 10, 635 (2004).

(431) Synthesis of ${ }^{11} \mathrm{C}$-Labeled $N, N^{\prime}$-Diphenylurea and Ethyl Phenylcarbamate by a RhodiumPromoted Carbonylation via [11C]Isocyanatobenzene Using Phenyl Azide and $\left[{ }^{11} \mathrm{C}\right]$ Carbon Monoxide. H. Doi, J. Barletta, M. Suzuki, R. Noyori, Y. Watanabe, and B. Långström, Org. Biomol. Chem., 2, 3063 (2004).

(432) Pursuing Practical Elegance in Chemical Synthesis. R. Noyori, Chem. Commun., 1807 (2005).

(433) Metal-Ligand Bifunctional Catalysis for Asymmetric Hydrogenation. R. Noyori, C. A. Sandoval, K. Muñiz, and T. Ohkuma, Phil. Trans. R. Soc. A, 363, 901 (2005).

(434) Asymmetric Hydrogenation of tert-Alkyl Ketones. T. Ohkuma, C. A. Sandoval, R. Srinivasan, Q. Lin, Y. Wei, K. Muñiz, and R. Noyori, J. Am. Chem. Soc., 127, 8288 (2005).

(435) Synthesis of the ABCD Ring of Gambierol. H. Furuta, M. Hase, R. Noyori, and Y. Mori, Org. Lett., 7, 4061 (2005).

(436) Preparation of Optically Active $(R, R)$-Hydrobenzoin from Benzoin or Benzil [1,2Ethanediol, 1,2-Diphenyl-, $(1 R, 2 R)-$. . T. Ikariya, S. Hashiguchi, K. Murata, and R. Noyori, Org. Synth., 82, 10 (2005).

(437) Solution Structures and Behavior of trans- $\mathrm{Ru}-\mathrm{H}\left(\eta^{1}-\mathrm{BH}_{4}\right)($ binap)(1,2-diamine) Complexes. C. A. Sandoval, Y. Yamaguchi, T. Ohkuma, K. Kato, and R. Noyori, J. Mag. Res., 44, 66-75 (2006).

(438) Hyperconjugative Electron-Delocalization Mechanism Controlling the Conformational Treference of Fluoroacetaldehyde and Methy Fluoruacetate. R. Sahnoun, Y. Fujimura, K. Kabuto, Y. Takeuchi, and R. Noyori, Bull. Chem. Soc. Jpn., 79, 555 (2006).

(439) Bifunctional Transition Metal-Based Molecular Catalysts for Asymmetric Syntheses. T. Ikariya, K. Murata, and R. Noyori, Org. Biomol. Chem., 4, 393 (2006).

(440) The Hydrogenation/Transfer Hydrogenation Network: Asymmetric Hydrogenation of Ketones with Chiral $\eta^{6}$-Arene/ $N$-Tosylethylenediamine-Ruthenium(II) Catalysts. $T$. Ohkuma, N. Utsumi, K. Tsutsumi, K. Murata, C. Sandoval, and R. Noyori, J. Am. Chem. Soc., 128, 8724 (2006).

(441) Mechanism of Asymmetric Hydrogenation of Acetophenone Catalyzed by Chiral $\eta^{6}$ Arene/ $N$-Tosylethylenediamine-Ruthenium(II) Complexes. C. Sandoval,, T. Ohkuma, N. Utsumi, K. Tsutsumi, K. Murata, and R. Noyori, Chem. Asian. J., 1-2, 102 (2006).

(442) Direct C-H Arylation of (Hetero)arenes with Aryl Iodides via Rhodium Catalysis. S. Yanagisawa, T. Sudo, R. Noyori, and K. Itami, J. Am. Chem. Soc., 128, 11748 (2006). 
(443) Asymmetric Hydrogenation of $\alpha$-Chloro Aromatic Ketones Catalyzed by $\eta^{6}$ Arene/TsDPEN-Ruthenium(II) Complexes. T. Ohkuma, K. Tsutsumi, N. Utsumi, N. Arai, R. Noyori, and K. Murata, Org. Lett., 9, 255 (2007).

(444) Rh-Catalyzed Arylation and Alkenylation of $\mathrm{C}_{60}$ Using Organoboron Compounds. M. Nambo, R. Noyori, and K. Itami, J. Am.Chem. Soc., 129, 8080 (2007). 


\section{REVIEWS, CHAPTERS, AND COMMENTARIES}

(1) Electronic Structure and Reactivity of Carbenes. H. Nozaki and R. Noyori, J. Synth. Org. Chem., Japan, 22, 603 (1964).

(2) Chemistry of Carbenoids. (Part I): Lithium- and Zinc-Carbenoids. H. Nozaki and R. Noyori, J. Synth. Org. Chem., Japan, 24, 519 (1966).

(3) Chemistry of Carbenoids. (Part II): Mercury- and Copper-Carbenoids. H. Nozaki and R. Noyori, J. Synth. Org. Chem., Japan, 24, 632 (1966).

(4) Stereochemistry of Reactions Involving Transition Metal Complexes. H. Takaya and R. Noyori, J. Synth. Org. Chem., Japan, 32, 2 (1974).

(5) Coupling Reactions via Transition Metal Complexes. R. Noyori, In "Transition Metal Organometallics in Organic Synthesis", H. Alper, Ed., Academic Press, New York, Vol. 1, Chapter 2, 1976.

(6) Organocopper Reagents. R. Noyori, J. Synth. Org. Chem., Japan, 34, 675 (1976).

(7) Recent Progress in Organic Synthesis Using Iron Carbonyl Complexes. H. Takaya and R. Noyori, J. Synth. Org. Chem., Japan, 35, 615 (1977).

(8) Synthesis of $C$-Nucleosides.-Using the Naturally Occurring Derivatives and Sugars. T. Sato and R. Noyori, J. Synth. Org. Chem., Japan, 38, 862 (1980).

(9) Synthesis of $C$-Nucleosides Starting from Non-carbohydrate Precursors. T. Sato and R. Noyori, J. Synth. Org. Chem., Japan, 38, 947 (1980).

(10) Toward the Highly Selective Organic Synthesis: Transition Metal Catalyzed Asymmetric Reactions. $\quad$ R. Noyori and H. Takaya, J. Synth. Org. Chem., Japan, 39, 522 (1981).

(11) Trialkylsilyl Triflates in Organic Synthesis. M. Suzuki and R. Noyori, J. Synth. Org. Chem., Japan, 40, 534 (1982).

(12) Advances in Organic Synthesis Promoted by Transition Metal Complexes. Y. Hayakawa and R. Noyori, J. Synth. Org. Chem., Japan, 40, 1013 (1982).

(13) Reductive Dehalogenation of Polyhalo Ketones with Low-Valent Metals and Related Reducing Agents. R. Noyori and Y. Hayakawa, In "Organic Reactions", W. G. Dauben, Ed., John Wiley \& Sons, New York, Vol. 29, Chapter 2, 1983.

(14) Structure, Stability, and Color Variation of Natural Anthocyanins (Research by T. Goto). M. Suzuki and R. Noyori, Chemtracts-Org. Chem., 1, 491 (1988).

(15) Enantioselective Catalysis with Metal Complexes. An Overview. R. Noyori and M. Kitamura, In "Modern Synthetic Methods 1989", R. Scheffold, Ed., Springer Verlag, Berlin, 1989, p. 115.

(16) Mutual Recognition of Enantiomers. R. Noyori and S. Okada, J. Synth. Org. Chem., Japan, 48, 447 (1990).

(17) Reduction of $\mathrm{C}=\mathrm{X}$ to $\mathrm{CHXH}$ by Chirally Modified Hydride Reagents. M. Nishizawa and R. Noyori, In "Comprehensive Organic Synthesis", B. M. Trost and I. Fleming, Eds., Pergamon Press, Oxford, Vol. 8, 1.7, 1991.

(18) Homogeneous Catalytic Hydrogenation of $\mathrm{C}=\mathrm{C}$ and $\mathrm{C} \equiv \mathrm{C}$. H. Takaya and R. Noyori, In "Comprehensive Organic Synthesis", B. M. Trost and I. Fleming, Eds., Pergamon Press, Oxford, Vol. 8, 3.2, 1991.

(19) Organic Synthesis: Current Status in Japan. R. Noyori, Science, 258, 584 (1992).

(20) Distannoxane as Reverse Micelle-Type Catalyst: Novel Solvent Effect on Reaction Rate of Transesterification (Research by J. Otera, S. Ioka, and H. Nozaki). Y. Hayakawa and R. Noyori, Chemtracts-Org. Chem., 3, 162 (1990).

(21) A Novel Preparative Method for Unsymmetrical Ethers by the Reaction of Cocrystals of Two Similarly Substituted Secondary Alcohols with Toluene-p-sulphonic Acid in the Solid State (Research by F. Toda and K. Okuda). M. Kitamura and R. Noyori, Chemtracts-Org. Chem., 5, 225 (1992). 
(22) Catalytic Asymmetric Synthesis. R. Noyori, J. Synth. Org. Chem., Japan, 50, 1131 (1992).

(23) Asymmetric Hydrogenation. H. Takaya, T. Ohta, and R. Noyori, In "Catalytic Asymmetric Synthesis", I. Ojima, Ed., VCH, Weinheim, Chapter 1, 1993.

(24) Molecular Mechanics and NOE Investigations of the Solution Structures of Intermediates in the $[\mathrm{Rh} \text { (chiral bisphosphine) }]^{+}$-Catalyzed Hydrogenation of Prochiral Enamides: ${ }^{103} \mathrm{Rh}$ Shielding and the Stereoselectivity of $\mathrm{H}_{2}$ Addition to Diastereomeric Olefin Complexes, T. Ohkuma and R. Noyori, Chemtracts-Org. Chem., 6, 325 (1994).

(25) Multiplication of Chirality via Molecular Catalysts. R. Noyori, Nikkei-Science, 24 (11), 42 (1994).

(26) Molecular Catalysis in Supercritical Fluids. T. Ikariya, P. G. Jessop, and R. Noyori, Shokubai, 36, 558 (1994).

(27) Homogeneous Hydrogenation of Carbon Dioxide with Transition Metal Complexes. T. Ikariya, P. G. Jessop, M. Tokunaga, and R. Noyori, J. Synth. Org. Chem., Japan, 52, 1032 (1994).

(28) Conjugate Addition-Enolate Trapping Reactions. M. Suzuki and R. Noyori, In "Organocopper Reagents, A Practical Approach", R. J. K. Taylor, Ed., Oxford University Press, Oxford, Chapter 9, 1994.

(29) Chemical Reactions in Supercritical Fluids. P. G. Jessop and R. Noyori, J. Synth. Org. Chem., Japan, 53, 358 (1995).

(30) Molecular Catalysis in Supercritical Fluids. T. Ikariya and R. Noyori, Chemistry Today, 1996 (5), 43.

(31) Enantioselective Hydrogenation of Simple Ketones. T. Ohkuma and R. Noyori, J. Synth. Org. Chem., Japan, 54, 553 (1996).

(32) Asymmetric Syntheses. R. Noyori and S. Hashiguchi, In "Applied Homogeneous Catalysis with Organometallic Compounds", B. Cornils and W. A. Herrmann, Eds, VCH, Weinheim, Vol. 1, 1996, p. 552.

(33) Phenylacetylene (Stereospecific Living Polymerization, Rh Complexes), Y. Kishimoto, R. Noyori, P. Eckerle, T. Miyatake and T. Ikariya, In "Polymeric Materials Encyclopedia", J. C. Salamone, Ed., CRC Press, 5051 (1996).

(34) Asymmetric Transfer Hydrogenation of Olefins and Ketones Catalyzed by Metal Complexes. S. Hashiguchi, A. Fujii, and R. Noyori, J. Synth. Org. Chem., Japan, 54, 818 (1996).

(35) Ozone-Mediated Nitration with Lower Oxides of Nitrogen (The Kyodai-Nitration), T. Suzuki and R. Noyori, Chemtracts-Org. Chem., 10, 813-817 (1997).

(36) Cell Growth Inhibition by Antitumor Prostaglandin and Its Modulation by MRP-GSXPump. K. Akimaru, M. Nakanishi, M.Suzuki, K. Furuta, R. Noyori, and T. Ishikawa, In "Eicosanoids and Other Bioactive Lipids in Cancer, Inflammation, and Radiation Injury", K. V. Hohn, S. Nigam, R. Jones, L. J. Marnett, and P. Y.-K. Wong, Eds., Plenum Press, New York, 1997, p. 387.

(37) Asymmetric Reduction of Imines. S. Hashiguchi, N. Uematsu, and R. Noyori, J. Synth Org. Chem., Japan, 55, 99 (1997).

(38) DNA Damage by Ptaquiloside, a Potent Bracken Carcinogen: Detection of Selective Strand Breaks and Identification of DNA Cleavage Products (Research by T. Kushida, M. Uesugi, Y. Sugiura, H. Kigoshi, H. Tanaka, J. Hirokawa, M. Ojika, and K. Yamada, and by H. Kogoshi, Y. Kitamura, T. Fujita, H. Ohashi, T. Atusmi, J. Takagi, T. Mutou, K. Yamada, T. Kusakabe, D. Sasaki, and Y. Sugigura), K. Sato, K. Zimmerman, and R. Noyori, Chemtracts-Org. Chem., 11, 512 (1998).

(39) Advancing Organic Synthesis. R. Noyori, J. Synth. Org. Chem., Japan., 56, 883 (1998).

(40) Carbonyl Hydrogenations. T. Ohkuma and R. Noyori, In "Transition Metals for Organic Synthesis", M. Beller and C. Bolm, Eds., Wiley-VCH, Vol. 2, 1.1.3, 1998. 
(41) Rate Acceleration in Nucleophilic Alkylation of Carbonyl Compounds with a New Template Containing Two Metallic Centers (Research by T. Ooi, M. Takahashi, and M. Maruoka), T. Ohkuma and R. Noyori, Chemtracts-Org. Chem., 11, 512 (1998).

(42) Hydrogenation of Carbonyl Groups. T. Ohkuma and R. Noyori, In "Comprehensive Asymmetric Catalysis", E. N. Jacobsen, A. Pfaltz, H. Yamamoto, Eds., Springer, Vol. 1, Chapter 6.1, 1999.

(43) Support for Research. R. Noyori, In "Research for the Next Generation", K. Kinoshta, Ed., Pilington Press, 1999, pp. 107-113.

(44) Chemical Studies on Plant Movement (Research by M. Ueda and S. Yamamura and by M. Ueda, M. Asano, and S. Yamamura). T. Suzuki and R. Noyori, Chemtracts-Org. Chem., 12, 797 (1999).

(45) Organic Reactions in Supercritical Fluids. T. Ikariya and R. Noyori, In "Transition Metal Catalysed Reactions", IUPAC Chemistry for the 21st Century Ser., S.-I. Murahashi and S. G. Davies, Eds, Blackwell Science, 1999, pp. 1-28.

(46) Preface (a tribute to Professor T. Mukaiyama). R. Noyori, Heterocycles, 52, 3 (2000).

(47) Asymmetric Hydrogenation. T. Ohkuma, M. Kitamura, and R. Noyori, In "Catalytic Asymmetric Synthesis", 2nd Ed., I. Ojima, Ed., Wiley-VCH, New York, Chapter 1, 2000.

(48) Supercritical Fluids for Organic Synthesis. R. Noyori and T. Ikariya, In "Stimulating Concepts in Chemistry", F. Vögtle, J. F. Stoddart, and M. Shibasaki, Eds., Wiley-VCH, New York, 2000, pp. 13-24.

(49) Asymmetric Syntheses. R. Noyori, S. Hashiguchi and T. Yamano, In "Applied Homogeneous Catalysis with Organometallic Compounds", B. Cornils and W. A. Herrmann, Eds, Wiley-VCH, Weinheim, Vol. 2, 2002, pp. 557-585.

(50) Asymmetric Catalysis: Science and Opportunities. R. Noyori, In "Les Prix Nobel 2001", The Nobel Foundation, Norstedts Tryckeri AB, Stockholm, 2002, pp. 177-215.

(51) Palladium-Catalyzed Rearrangements of Oxygen Functions. M. Suzuki, T. Hosoya, and R. Noyori, In "Organopalladium Chemistry for Organic Synthesis", E. Negishi Ed., John Wiley \& Sons, New York, Chapter IX.2.2, 2002.

(52) Preface. R. Noyori, In "My Favorite Organic Synthesis", The Society of Synthetic Organic Chemistry, Kagaku-Dojin Publishing Co., 2002.

(53) Asymmetric Hydrogenation of Olefins Catalyzed by BINAP-Ru(II) Complexes. R. Noyori and M. Kitamura, In "My Favorite Organic Synthesis", The Society of Synthetic Organic Chemistry, Kagaku-Dojin Publishing Co., 2002, p. 142.

(54) Stereoselective Hydrogenation of Ketones Catalyzed by Ru(II) Complexes. R. Noyori and T. Ohkuma, In "My Favorite Organic Synthesis", The Society of Synthetic Organic Chemistry, Kagaku-Dojin Publishing Co., 2002, p. 144.

(55) Catalytic Hydrogenation: A Core Technology in Synthesis. R. Noyori, Adv. Synth. Catal., 345, 1 (2003).

(56) Preface. R. Noyori, In "The Chemical Society of Japan. A 125-Year Quest for Excellence", The Chemical Society of Japan, 2003, p i.

(57) Ryoji Noyori (Profile), Green Chemistry, G37 (2003).

(58) Hydrogenation of Carbonyl Groups. T. Ohkuma and R. Noyori, In "Comprehensive Asymmetric Catalysis", Supplement I, E. N. Jacobsen, A. Pfaltz, and H. Yamamoto, Eds., Springer, Berlin, 2003, pp. 1-41.

(59) Hydrogenation of Imino Groups. T. Ohkuma and R. Noyori, In "Comprehensive Asymmetric Catalysis", Supplement I, E. N. Jacobsen, A. Pfaltz, and H. Yamamoto, Eds., Springer, Berlin, 2003, pp. 43-53.

(60) Hydrosilylation of Carbony and Imino Groups. T. Ohkuma and R. Noyori, In "Comprehensive Asymmetric Catalysis", Supplement I, E. N. Jacobsen, A. Pfaltz, and H. Yamamoto, Eds., Springer, Berlin, 2003, pp. 55-71. 
(61) (S,S)-1,2-Diphenylethylenediamine. T. Ohkuma and R. Noyori, In "Handbook of Reagints for Organic Synthesis: Chiral Reagents for Asymmetric Synthesis", L. A. Paquette, Ed., Wiley, Chichester, 2003, pp. 304-308.

(62) Advances in Homogeneous, Heterogeneous, and Biphasic Metal-Catalyzed Reactions in Dense-Phase Carbon Dioxide. T. Ikariya, R. Noyori, M. B. Abrams, C. G. Carter, G. B. Jacobson, F. Liu, D. R. Pesiri, and W. Tumas, In "Green Chemistry Using Liquid and Supercritical Carbon Dioxide", J. M. DeSimone and W. Tumas, Eds., Oxford University Press, Oxford, 2003, pp. 17-47.

(63) Carbon Dioxide as a Reactant and Solvent in Catalysis. T. Ikariya and R. Noyori, In "Green Chemistry Using Liquid and Supercritical Carbon Dioxide", J. M. DeSimone and W. Tumas, Eds., Oxford University Press, Oxford, 2003, pp. 48-63.

(64) Carbonyl Hydrogenation. T. Ohkuma and R. Noyori, In "Transition Metals for Organic Synthesis", 2nd Edition, M. Beller and C. Bolm, Eds., Wiley-VCH, Weinheim, 2004, pp. 29-113.

(65) Hydroboration of Carbonyl Groups. T. Ohkuma and R. Noyori, In "Comprehensive Asymmetric Catalysis", Supplement II, E. N. Jacobsen, A. Pfaltz, and H. Yamamoto, Eds., Springer, Berlin, 2004, pp. 1-41.

(66) Hydroboration of Imino Groups. T. Ohkuma and R. Noyori, In "Comprehensive Asymmetric Catalysis", Supplement II, E. N. Jacobsen, A. Pfaltz, and H. Yamamoto, Eds., Springer, Berlin, 2004, pp. 43-53.

(67) Hydroboration of Carbonyl and Imino Groups. T. Ohkuma and R. Noyori, In "Comprehensive Asymmetric Catalysis", Supplement II, E. N. Jacobsen, A. Pfaltz, and H. Yamamoto, Eds., Springer, Berlin, 2004, pp. 55-71.

(68) Hydroboration of Carbonyl Groups. T. Ohkuma and R. Noyori, In "Comprehensive Asymmetric Catalysis", Supplement II, E. N. Jacobsen, A. Pfaltz, and H. Yamamoto, Eds., Springer, Berlin, 2004, pp. 7-19.

(69) Hydrogenation and Transfer Hydrogenation. M. Kitamura and R. Noyori, In "Ruthenium in Organic Synthesis", S.-I. Murahashi, Ed., Wiley-VCH, Weinheim, 2004, pp. 3-52.

(70) Asymmetric Catalysis: Role in Biomedical Science and Technology. R. Noyori, In "Discovery to Delivery: BioVision 2004", I. Serageldin and G. J. Persley, Eds., Bibliotheca Alexandrina, The Doyle Foundation, 2005. Chapter 4.

(71) Preface (a tribute to Professor Howard Alper), Can. J. Chem., 83, xix (2005).

(72) A Quantum Leap. R. Noyori, Chem. Asian J., 1-2, 3 (2006).

(73) Message from Nobel Laureates to Young People(5), Professor Ryoji Noyori, 2001 Nobel Prize in Chemistry, Chem. Educ. Intn., 7, No.1, AN-1 (2006).

(74) Asymmetric Hydrogenation through Metal-Ligand Bifunctional Catalysis. R. Noyori, T. Ohkuma, C. A. Sandoval, and K. Muñiz, In "Asymmetric Synthesis - The Essentials," M. Christmann and S. Bräse, Ed., Wiley-VCH, Weinheim, 2007, pp. 337-341.

(75) Pioneering Perspectives on Asymmetric Hydrogenation. W. S. Knowles and R. Noyori, Acc. Chem. Res. 40, 1238-1239 (2007). 


\section{BOOK}

"Asymmetric Catalysis in Organic Synthesis," R. Noyori, John Wiley \& Sons, New York, 1994. 